\title{
Estimating Chemical Errors in Large-scale Simulations of Aircraft Emissions
}

\author{
Fujung Tsai ${ }^{1, *}$ and Chris J. Walcek ${ }^{2}$ \\ (Manuscript received 21 March 2000, in final form 12 February 2001)
}

\begin{abstract}
Calculations of a relatively comprehensive chemical reaction mechanism applied to individual parcels of aircraft emissions under upper tropospheric conditions show that over a typical residence time of air in the upper troposphere, each aircraft-emitted $\mathrm{NO}_{\mathrm{x}}$ molecule produces about 2-3 molecules of $\mathrm{O}_{3}$ per day as long as the reactive $\mathrm{NO}_{y}$ remains in the upper troposphere. In the upper tropospheric environment characterized by low ambient turbulence and appreciable vertical wind shear, aircraft plumes grow slowly during initial stages, and take several days to diffuse to a size comparable to the grid volume used by global-scale Eulerian models. By assuming aircraft emissions are immediately diluted into a larger grid cell volume, larger-scale models will overestimate the calculated $\mathrm{O}_{3}$ production by 20 to $30 \%$. This overestimate depends on the vertical diffusion efficiency, vertical wind shear, and $\mathrm{NO}_{x}$ concentrations in the ambient environment. This overestimate can be compensated for in larger scale models by reducing the reaction coefficient of the $\mathrm{NO}+\mathrm{HO}_{2}$ reaction by less than $3 \%$ under typical upper tropospheric conditions.
\end{abstract}

(Key words: Aircraft emissions, Aircraft plumes, Larger-scale models)

\section{INTRODUCTION}

With the increased demand for aircraft transportation, pollution resulting from aircraft emissions has been identified as a potential problem to ambient environment. Aircraft emissions include oxides of nitrogen $\left(\mathrm{NO}_{x}\right.$, or $\left.\mathrm{NO}+\mathrm{NO}_{2}\right)$, nonmethane hydrocarbons ( $\mathrm{NMHC}$ ), carbon monoxide (CO), and particles. Globally, over half of the subsonic aircraft emissions are released at flight altitudes between 9 to $13 \mathrm{~km}$, where aircraft spend most of their air time (Baughcum 1997). At these altitudes, both tropospheric and stratospheric conditions are

\footnotetext{
${ }^{1}$ Department of Atmospheric Science, National Taiwan University, Taipei, Taiwan

2 Department of Atmospheric Science, State University of New York at Albany, Albany, NY, USA

* Corresponding author address: Dr. Fujung Tsai, Department of Atmospheric Science, No. 61, Ln. 144, Sec. 4, Keelung Rd., Tajpei 106, Taiwan; E-mail: fujung@aerosol.as.ntu.edu.tw
} 
common, and the photochemical properties are distinctively different from those of the lower troposphere. In the boundary layer, chemical removal proceeds rapidly through dynamic processes such as turbulent mixing and dry deposition. In the upper troposphere and lower stratosphere, however, little turbulent mixing occurs, and the atmosphere is highly stable. Only relatively intermittent and infrequent deep convective clouds reach these heights and induce mixing. Thus, the residence times of pollutants in the upper troposphere and lower stratosphere are usually longer. Occasionally, anthropogenic emissions are lifted from surface to this height through deep convective mixing, while most of the time the ambient conditions remain rather unpolluted. Aircraft are the only anthropogenic emissions directly released at these heights, and these emissions may increase the burden of primary and secondary pollutants at these altitudes.

Aircraft emissions have been linked to changes in upper tropospheric $\mathrm{NO}_{x}$ and $\mathrm{O}_{3}$ (Hidalgo and Crutzen 1977; Derwent 1982; Beck et al. 1990; Brasseur et al. 1996; Johnson and Stevenson 1996; Schumann 1997; Meijer et al. 2000). The concentration of $\mathrm{NO}_{x}$ in the upper troposphere is usually low, and thus it is considered a " $\mathrm{NO}_{x}$-limited" region where $\mathrm{O}_{3}$ concentrations are influenced by small changes in ambient $\mathrm{NO}_{x}$ concentrations. By directly emitting $\mathrm{NO}_{x}$ and other pollutants to the upper troposphere, the concentrations of $\mathrm{NO}_{x}$ and $\mathrm{O}_{3}$ can be enhanced $\mathrm{O}_{3}$ and $\mathrm{NO}_{x}$ perturbations will affect $\mathrm{OH}$ concentrations and, in turn, affect other greenhouse gases such as methane whose tropospheric budget is regulated by HO. Previous climate simulations have also shown that radiative forcing of surface temperature is sensitive to $\mathrm{O}_{3}$ concentrations in the upper troposphere (Wang et al. 1980; Lacis et al. 1990). Since $\mathrm{O}_{3}$ is a greenhouse gas absorbing terrestrial IR radiation, aircraft can potentially contribute to climate change.

Small-scale modeling studies of aircraft emissions have been used to quantify the emission impacts on tropospheric chemistry. Using a large eddy-resolving model, Dürbeck and Gerz (1995) estimated the effective diffusion coefficient of aircraft plumes several minutes after emissions under different wind shear conditions in the upper troposphere. Later, Dürbeck and Gerz (1996) found that in the upper troposphere, vertical wind shear in combination with small ambient diffusion enlarges the cross section of an exhaust plume and increases the dilution rate. For a given length of aircraft plume, Dürbeck and Gerz found that it takes about half a day to two days to be homogeneously mixed to a volume of air with $4.3 \mathrm{~km}$ wide by $1.1 \mathrm{~km}$ vertical in cross section depending on the mean wind shear (Dürbeck and Gerz 1995; Konopka 1996). Schumann et al. (1995) measured aircraft plumes in the North Atlantic flight corridor, where they inferred diffusion coefficients for the dispersing contrails. They also found that the vertical wind shear dominates the lateral dispersion of aircraft exhaust plumes after about an hour following emission.

Chemical reactions were included in the rajectory box model by Danilin et al. (1994) to calculate the short-term chemical transformations of aircraft emissions. In their study, the initial aircraft pollutants were assumed to be homogeneously mixed inside the aircraft plumes, and diluted with the ambient air as the plume expanded with time. The effects of heterogeneous reactions on aircraft-emitted aerosols and ice contrail particles were also considered. According to their plume scale calculations, ozone perturbations due to aircraft emissions were about $0.6 \%$ in the upper troposphere 40 hours after emissions, which corresponds to about 1-2 molecules of additional $\mathrm{O}_{3}$ per $\mathrm{NO}_{x}$ molecule emitted. A multi-layer aircraft plume 
with chemistry was used by Kraabøl et al. (1996) to calculate the chemical conversion of $\mathrm{NO}_{x}$ and the time evolution of $\mathrm{O}_{3}$ while the aircraft plume was mixing with the ambient air. Aircraft plumes in this multi-layer model were assumed to be in a Gaussian distribution, and the initial concentrations of the emitted chemical species were distributed uniformly within each concentric layer of the model. Diffusion occurs between these multiple layers and with the ambient air, which is the outermost layer. By applying this multi-layer plume model, Kraabol et al. concluded that aircraft plumes expand rapidly during the first few minutes after being emitted when aircraft-generated turbulence is present. They indicated that about $6-7 \%$ of the emitted $\mathrm{NO}_{\mathrm{x}}$ were converted to other nitrogen species during the first 4 hours, and ozone increased up to $0.8 \mathrm{ppb}$ near the core of the aircraft plume. Hayman and Markiewicz (1996) also used a multi-layer plume model to calculate $\mathrm{O}_{3}$ production due to aircraft emissions of $\mathrm{NO}_{x}$ and $\mathrm{NMHC}$ in a two-day simulation. They found that aircraft NMHC emissions have a negligible effect on $\mathrm{O}_{3}$ in the upper troposphere, while aircraft $\mathrm{NO}_{x}$ emissions have far more important effects. Applying a plume scale model to estimate the chemical conversion of aircraft emitted species, Petry et al. (1998) studied the effects of inhomogeneity of aircraft emissions in larger volumes of air and found that the impacts on $\mathrm{O}_{3}$ can be appreciably overestimated in meso- and largescale model calculations.

In this plume-scale study, a plume growth and chemistry model is developed to evaluate the chemical evolution of a parcel of aircraft-emitted $\mathrm{NO}_{x}$ as the contrail slowly dilutes into the background air. In most global or mesoscale Eulerian model studies of the chemical impacts of aircraft emissions, the emissions are immediately diluted throughout each model grid box where emissions are occurring, and the chemical effects of the artificially diluted emissions are evaluated. In the real atmosphere, however, the initial aircraft plumes are small compared to global or mesoscale model grid volumes. Under typical conditions, it takes up to several days or more for the emissions from individual aircraft plumes to be dispersed to the resolvable size ranges of large-scale models. The chemistry of this expanding plume is not necessarily the same as that of a plume instantly diluted to the volume of a global or mesoscale model grid cell. The purpose of this plume scale study, therefore, is to evaluate and quantify the errors in calculated $\mathrm{O}_{3}$ impacts generated by artificially diluting plumes of aircraft $\mathrm{NO}_{x}$ to large-scale sizes.

In this study, a crude model which instantly dilutes aircraft emissions over a larger air volume is compared with a more realistic model where aircraft $\mathrm{NO}_{\mathrm{x}}$ are added to a small contrail that slowly grows and diffuses to fill the same larger air volume. The overestimates of calculated aircraft impacts due to instant dilution of aircraft emissions under typical atmospheric conditions are quantified. An adjustment method which reduces the $\mathrm{O}_{3}$ formation rate calculated by the crude model is proposed as a method to alleviate this error in larger-scale atmospheric models.

\section{PLUME CHEMISTRY MODEL}

To estimate the errors that are inherent in most global-scale or mesoscale simulations of aircraft emissions, two models of aircraft emissions into the upper troposphere are developed 
and compared, as shown schematically in Fig. 1. The first more accurate and realistic model simulates aircraft plumes slowly expanding with time in a larger-scale volume of air in the upper roposphere. The second more simplified model assumes that aircraft $\mathrm{NO}_{x}$ emissions are immediately diluted throughout the same larger-scale air volume. For both models, the largerscale air volume over which aircraft impacts are being evaluated corresponds to the grid volumes used by global-scale atmospheric models in the upper troposphere. The two plume models use the same meteorology and background initial concentrations of chemicals, and are integrated forward in time. Ozone perturbations calculated by both models are compared.

Both models are essentially "Lagrangian" in nature and explicitly simulate the chemical evolution of a unit length of aircraft contrail within a larger volume of air. These Lagrangian box models essentially follow the unit cross-sections of aircraft plumes as they are carried by the mean winds around the earth. The mean wind in the large-scale air volume is defined to be zero, but the vertical shear of the wind speed perpendicular to the plume axes deforms the individual aircraft plumes within the air volume as time progresses.

\subsection{Growing Plume Model}

In the growing plume model, several aircraft contrails have been assumed to transverse through an air volume where aircraft impacts are considered (Fig. 2). The y-axis of the box model is defined to be oriented along the plume body as shown in Fig. 1a. The aircraft plumes are surrounded by ambient air that is not influenced by aircraft emissions. The conditions of the model grid volume are designed to be similar to the shear environment of the upper troposphere. It is assumed that the aircraft plumes have just entered a dispersion stage, a few minutes after emission, aircraft-generated turbulence has dissipated, and ambient wind shear and turbulent or molecular diffusion determine plume dispersion.
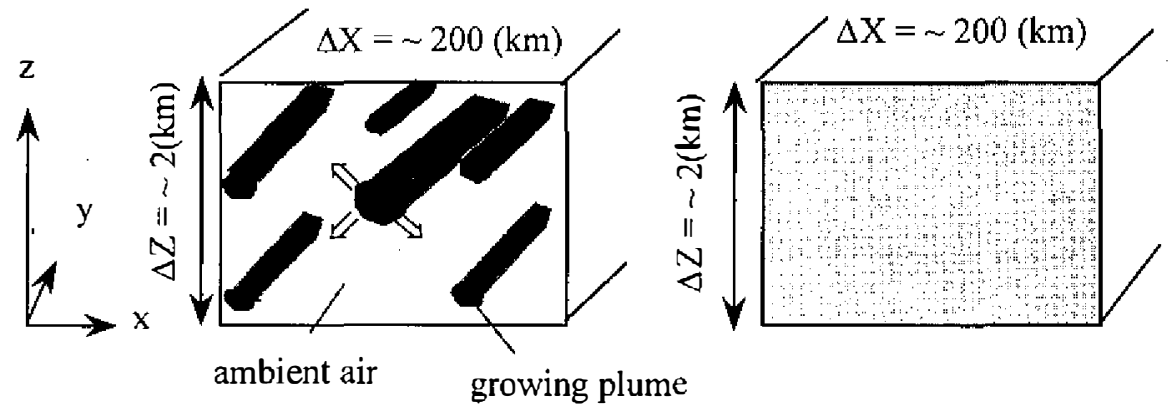

(a) growing plume model

(b) instantly diluted plume model

Fig. 1. Schematic diagram of the two plume models of a flight corridor through which several aircraft have traversed. (a) The growing plume model, which shows aircraft plumes slowly growing with time inside a largescale model grid cell. (b) The instantly diluted plume, in which the aircraft emissions are immediately diluted throughout the model grid cell after they are emitted. 


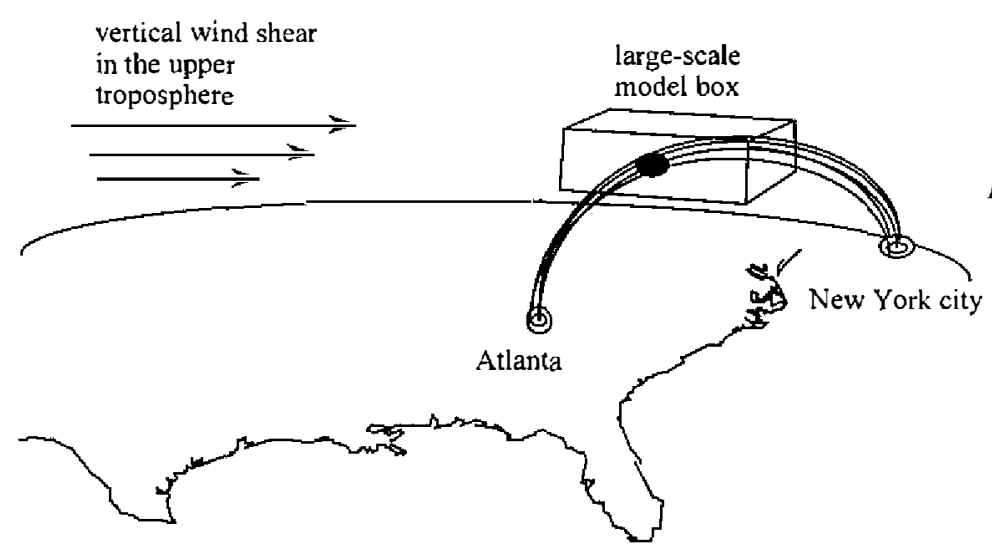

Fig. 2. Schematic diagram of aircraft contrails transversing through a model grid box located in the upper troposphere.

At aircraft emission aititudes, wind speed typically increases with height. In adding this wind shear to the model grid volume, the wind shear is divided into two components: one ( $x$ component) perpendicular to the plume body; and the other (y-component) blowing along the plume body. The plume stretches due to the x-component of the vertical shear that is perpendicular to the plume body. The y-component of the wind shear is parallel to the aircraft plumes and does not affect the plume growth rate.

In this shear environment of the upper troposphere, the dispersion of aircraft plumes is controlled by molecular and turbulent diffusion as well as wind advection, which varies with height. The concentration tendency of an aircraft emitted species (C) under this environment can be described by the following advective/diffusion equation:

$$
\frac{\partial C}{\partial t}=-u \frac{\partial C}{\partial x}+K_{z} \frac{\partial^{2} C}{\partial z^{2}}+K_{x} \frac{\partial^{2} C}{\partial x^{2}}
$$

where $x$ and $z$ are the horizontal and vertical distances from the plume center, respectively; the wind speed $u=\frac{\partial u}{\partial z} z$, and $\frac{\partial u}{\partial z}$ is the vertical wind shear perpendicular to the plume axis; and $K_{x}$ and $K_{z}$ are the horizontal and vertical diffusion coefficients, respectively. If vertical wind shear $\frac{\partial u}{\partial z}$ is constant, the solution to this equation is a Gaussian-like function (Konopka 1995):

$$
C(x, z, t)=\frac{Q}{2 \pi \sqrt{\sigma_{z}^{2} \sigma_{x}^{2}-\sigma_{s}^{4}}} \exp \left[\frac{-\left(x^{2} \sigma_{z}^{2}-2 x z \sigma_{s}^{2}+z^{2} \sigma_{x}^{2}\right)}{2\left(\sigma_{z}^{2} \sigma_{x}^{2}-\sigma_{s}^{4}\right)}\right],
$$

where the emission rate $Q$ is defined as the mass of pollutants emitted per meter of contrail. The horizontal $\left(\sigma_{x}\right)$, shear axis $\left(\sigma_{s}\right)$ and vertical $\left(\sigma_{z}\right)$ standard deviations are given by: 


$$
\begin{gathered}
\sigma_{x}^{2}=\frac{2}{3}\left[\frac{\partial u}{\partial z}\right]^{2} K_{z} t^{3}+2 K_{x} t+\left[\frac{\partial u}{\partial z} \sigma_{z 0} t\right]^{2}+\sigma_{x 0}^{2}, \\
\sigma_{s}^{2}=\frac{\partial u}{\partial z} K_{z} t^{2}+\frac{\partial u}{\partial z} \sigma_{z 0}^{2} t, \\
\sigma_{z}^{2}=2 K_{z} t+\sigma_{z 0}^{2},
\end{gathered}
$$

where the $\sigma_{x 0}$ and $\sigma_{z 0}$ are the initial horizontal and vertical standard deviations, respectively, and $t$ is time after emission.

For this growing plume model study, the model grid volume is subdivided into two chemical regions: the aircraft plume region, which increases in size with time as shown in Fig. 3, and the ambient environment. Pollutants in the aircraft plume region are confined to the volume of the growing Gaussian-like plume described using Eqs. $(1-4)$, in which pollutants are assumed to be uniformly mixed as shown in Fig. 4. According to Equation (1), the distribution of plume concentrations is Gaussian in shape, where higher concentrations of pollutants are in the core of aircraft contrails and the concentrations decrease with distance from the core. Thus there is no obvious physical boundary to the region impacted by the aircraft emissions. However, one can reasonably approximate the plume boundaries by assuming that aircraft-emitted pollutants are confined within a certain inner portion of the Gaussian plume, where the plume boundary is chosen so as to minimize the discrepancies between a well-mixed plume occupying a distinct Gaussian envelope and the exact smoothly-varying Gaussian distribution described above. The cross sectional area of the plume containing aircraft emissions is defined to be

$$
A=1.21 \pi \sqrt{\sigma_{z}^{2}} \sigma_{x}^{2}-\overline{\sigma_{s}^{4}},
$$

which increases with time as the standard deviations $(\sigma)$ expand. The 1.21 factor arises from the conversion of a smooth-varying Gaussian to the best-fitting well-mixed concentration profile.

As the aircraft plumes grow inside the larger air volume, the initially high concentrations of pollutants are diluted with ambient air. For calculating the concentration tendency $(\partial C / \partial t)$ of reactive species inside the growing plume, the chemical production and loss of the reactive species are first calculated in both the ambient air containing no aircraft emissions and the

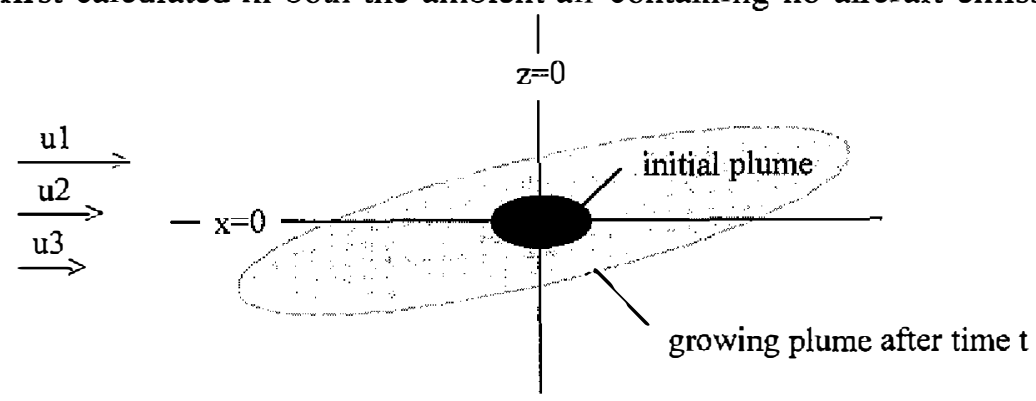

Fig. 3. Plume cross section initially and at time $\mathrm{t}$, with $\mathrm{u} 1, \mathrm{u} 2$, and $\mathrm{u} 3$ representing the horizontal winds perpendicular to the plume cross section. 


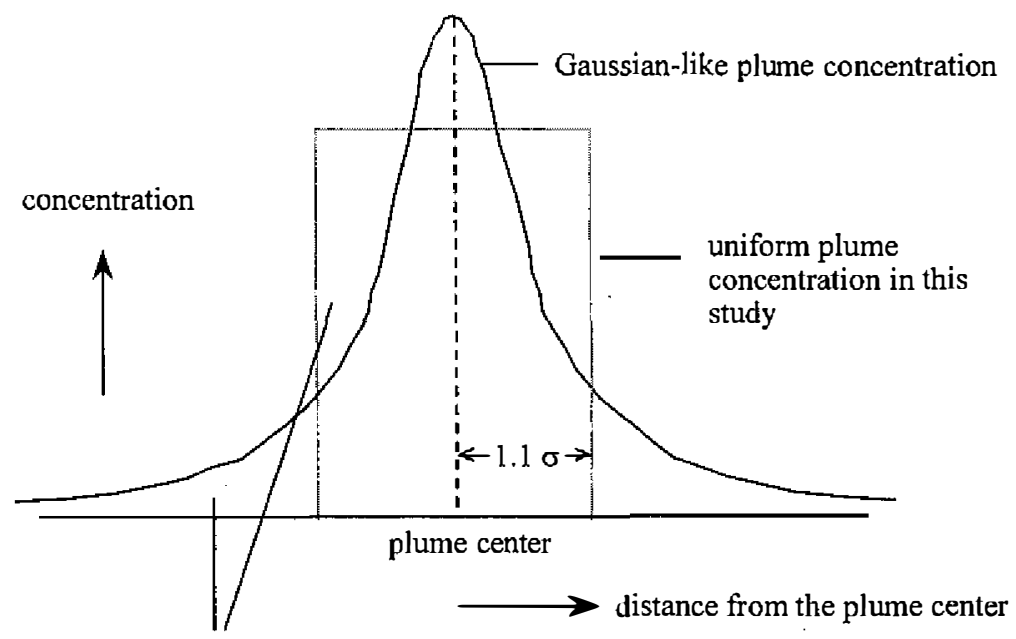

error of pollutant mass generated by assuming a uniform distribution of

pollutants inside the emitted aircraft plume.

Fig. 4. Schematic diagram of Gaussian-like plume and the assumed uniform plume in this study.

aircraft plumes initially containing higher mixing ratios of aircraft emitted compounds. Then, additional concentration tendencies due to entrainment of the ambient air are added to the concentration tendencies in aircraft plumes. The chemistry equations for this entraining plume and the ambient air in the growing plume model thus can be described as follows:

$$
\begin{gathered}
\frac{\partial C_{p}}{\partial t}=P_{p}-L_{p}+\left(C_{e}-C_{p}\right)\left(\frac{d V}{d t}\right)\left(\frac{1}{V}\right), \\
\frac{\partial C_{e}}{\partial t}=P_{e}-L_{e},
\end{gathered}
$$

where $C_{p}$ and $C_{e}$ are concentrations of chemical species in the entraining plumes and ambient environment; $V$ is plume volume, and $d V / d t$ is the time rate change of the plume volume. The $P$ and $L$ terms on the right hand side of Eqs. (6) and (7) represent chemical production and loss, respectively. The third term on the right hand side of Eq. (6) represents the dilution and entrainment of ambient chemical constituents into the growing aircraft plume. The concentrations of the reactive chemicals in the growing aircraft plume, therefore, change with time due to chemical production and loss, as well as due to plume growth and mixing with ambient air. Since the combined model simulates the chemistry of a unit length of an aircraft plume, the plume volume is the area per meter of contrail length. Thus, plume area $A$ and plume volume $V$ are used equivalently in evaluating the plume growth rate.

For comparing species concentration at any time with the instantly diluted plume case, the average concentration $\bar{C}$ over the entire model consists of the volume-weighted average of the concentrations inside the entraining aircraft plume and the concentrations in the ambient 
air.

$$
\bar{C}=C_{p} v+C_{e}(1-v),
$$

where $v$ is the plume volume fraction relative to the larger model grid volume. When the entraining aircraft plume grows to the model grid volume, the plume volume fraction $v$ reaches $100 \%$, and the aircraft emissions are essentially well mixed into the larger volume of air considered for estimating aircraft impacts: At this time, the averaged concentrations of pollutants in the growing plume model equal the concentrations of the entraining aircraft plume.

The ambient vertical wind shear $(\partial u / \partial z)$ and diffusion coefficients $\left(K_{z}, K_{x}\right)$ strongly influence the plume growth rate. The vertical and horizontal diffusion coefficients in the upper troposphere were estimated by Schumann et al. (1995) based on aircraft turbulence measurements. They found that upper tropospheric air contains little turbulent mixing. The turbulent diffusion coefficients they inferred from vertical velocity variance and a model of stable Brunt-Väisälä oscillations is about $0.05 \mathrm{~m}^{2} \mathrm{~s}^{-1}$. Using another inferential approach derived from direct measurements of turbulent dissipation rates, they inferred essentially no turbulent diffusion as the calculated diffusion coefficients are in the molecular diffusion range. Other measurements have shown that the upper troposphere, where aircraft pollutants are emitted, generally has high static stability, and thus vertical motions are small and mixing is much slower in the vertical than in the horizontal (Pearson et al. 1983; Nastrom and Gage 1985; Nastrom et al. 1987). The typical vertical wind shear in the upper troposphere is about $4 \times 10^{-3} \mathrm{~s}^{-1}$ according to the mean wind profiles of the atmosphere and observations compiled by Schumann et al. (1995). Figure 5 shows plume size growing with time under typical atmospheric conditions, with vertical diffusion coefficient $K_{z}=0.05 \mathrm{~m}^{2} \mathrm{~s}^{-1}$, horizontal diffusion coefficient $K_{x}=10 \mathrm{~m}^{2} \mathrm{~s}^{-1}$, wind shear $\partial u / \partial z=4 \times 10^{-3} \mathrm{~s}^{-1}$, initial plume size $\sigma_{x 0}=200 \mathrm{~m}$ and $\sigma_{z 0}=50 \mathrm{~m}$. The relative plume area $A / A_{0}=\sqrt{\sigma_{z}^{2} \sigma_{x}^{2}-\sigma_{s}^{4}} / \sigma_{x 0} \sigma_{z 0}$ is derived from Equation (5), and the initial plume size $A_{0}$ is $38000 \mathrm{~m}^{2}$. The initial plume size and its relative dimensions have only a minor impact on overall plume dispersion for time periods longer than a few hours after aircraft emissions. Figure 5 shows that it takes about 10 days for an individual plume to

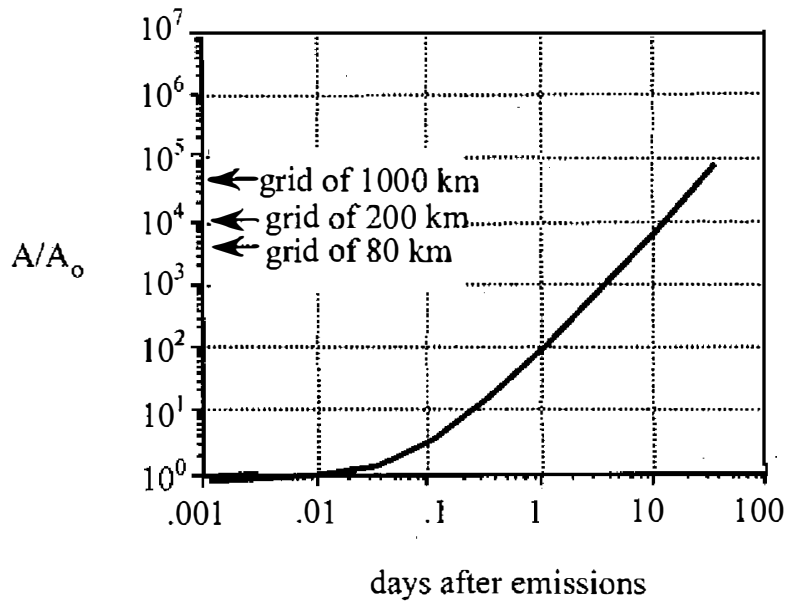

Fig. 5. Aircraft plume growth rate as a function of days after emissions. $A / A_{0}$ is the size of the plume crosssection relative to the initial size. The diffusion coefficients and vertical wind shear used in this study are $\mathrm{K}_{\mathrm{z}}=0.05 \mathrm{~m}^{2} / \mathrm{s}, \partial \mathrm{u} /$ $\partial \mathrm{z}=4 \times 10^{-3} \mathrm{~s}^{-1}$, and $\mathrm{K}_{\mathrm{x}}=10 \mathrm{~m}^{2} / \mathrm{s}$. The relative sizes of larger model grid with resolution of 1000, 200 and $80 \mathrm{~km}$ are also indicated. 
grow to the size of a larger scale air volume of $200 \mathrm{~km}$ horizontally under typical upper tropospheric conditions.

\subsection{Instantly Diluted Plume Model}

Global and many regional models of aircraft emissions implicitly assume that aircraft emissions are immediately diluted throughout the entire volume of the model grid cell where emissions are occurring. In the upper troposphere, horizontal model resolution is typically greater than $200 \times 200 \mathrm{~km}^{2}$, and vertical resolution is $1-4 \mathrm{~km}$. Here we mimic the behavior of these larger-scale models by adding aircraft emissions uniformly at the initial time as shown schematically in Fig. 1b. Chemical tendencies due to production and loss only are calculated for this diluted environment and are compared with the chemical tendency averaged from the growing plume model.

\section{METEOROLOGICAL, CHEMICAL AND INITIAL PLUME CONDITIONS}

In order to estimate the errors of calculated aircraft impacts due to instantaneously spreading emissions over a wide area initially, the two plume models described above are integrated forward in time, and the calculations of the two models are compared. Table 1 lists the meteorological conditions used for this comparison. These conditions are representative of the upper troposphere at aircraft cruising altitudes. In both plume models, there are 14 aircraft plumes inside the larger grid volume. This plume density represents a typical plume density within the larger-scale air volume considered in the study for conditions typical of a polluted flight corridor in the eastern U. S. According to NASA emission inventories (Metwally 1995; Baughcum 1996), $\mathrm{NO}_{x}$ emission rates are about $146 \mathrm{ppt} /$ day averaged over a global-size model grid volume in the northeast U. S. flight corridor. Typical aircraft emit $0.1-0.2 \mathrm{~kg} \mathrm{NO}$ per kilometer traveled (Petry et al. 1998), and for typical wind speeds at flight altitudes, the $\mathrm{NO}_{x}$ emission rate of $146 \mathrm{ppt} / \mathrm{day}$ represents about 14 transients during the time it takes air within a typical GCM grid to be replaced by advection.

If the $\mathrm{NO}_{\mathrm{x}}$ emitted per kilometer travel is homogeneously diluted to the initial aircraft plume volume defined in Table 1, the $\mathrm{NO}_{\mathrm{x}}$ concentration in the initial aircraft plume of the growing plume model is approximately $10 \mathrm{ppb}$, which is consistent with previous plume-scale modeling studies of aircraft impacts (Danilin et al. 1994; Konopka 1996). If the same amount of $\mathrm{NO}_{x}$ emissions is instantly diluted to the larger scale volume instead of to the initial aircraft plume volume, the initial $\mathrm{NO}_{x}$ perturbation is $13.3 \mathrm{ppt}$. As listed in Table 1, the air volume over which aircraft impacts are calculated in this study has a size of $200 \mathrm{~km}$ in the horizontal by $2 \mathrm{~km}$ in the vertical. The initial 14 aircraft plumes of $50 \times 200 \mathrm{~m}^{2}$ in cross section occupy about $0.13 \%$ of the larger air volume.

Since this study considers the impacts of aircraft plumes under typical flight corridor conditions, the density of the aircraft emissions is the major concern regardless of the size of the larger air volume considered. If a smaller averaging air volume is considered, fewer aircraft plumes will be present in the averaging volume corresponding to the same emission density, and the time for these fewer aircraft plumes to expand to the size of the smaller air 
Table 1. Meteorological conditions and aircraft plume parameters for two plume models.

\begin{tabular}{ll}
\hline Temperature $(\mathrm{T})$ & $223 \mathrm{~K}$ \\
Pressure $(\mathrm{P})$ & $265 \mathrm{PA}$ \\
Water vapor & $80 \mathrm{ppm}$ \\
Box size & $200 \mathrm{~km}($ width $) \times 2 \mathrm{~km}$ (height) \\
Vertical wind shear & $4 \times 10^{-3} 1 / \mathrm{s}$ \\
Plume initial horizontal dispersion $\left(\sigma_{\mathrm{x} 0}\right)$ & $200 \mathrm{~m}$ \\
Plume initial vertical dispersion $\left(\sigma_{\mathrm{z} 0}\right)$ & $50 \mathrm{~m}$ \\
Vertical diffusion coefficient $\left(\mathrm{K}_{\mathrm{z}}\right)$ & $5 \times 10^{-2} \mathrm{~m}^{2} / \mathrm{s}$ \\
Horizontal diffusion coefficient $\left(\mathrm{K}_{\mathrm{x}}\right)$ & $10 \mathrm{~m} / \mathrm{s}$ \\
Plume number in the box grid & 14 \\
Simulation start time & $9 \mathrm{AM}$ \\
\hline
\end{tabular}

Table 2. Initial steady state chemical concentrations ( $\mathrm{ppb}$ or $\mathrm{ppbC}$ ) for major species.

\begin{tabular}{ll}
$\mathrm{NO}_{\mathrm{x}}$ & 0.038 \\
$\mathrm{O}_{3}$ & 156.6 \\
$\mathrm{HNO}_{3}$ & 0.46 \\
$\mathrm{H}_{2} \mathrm{O}_{2}$ & 0.15 \\
$\mathrm{HCHO}$ & 0.028 \\
$\mathrm{PAN}_{\mathrm{CO}}$ & 0.060 \\
$\mathrm{HNO}_{4}$ & 89 \\
$\mathrm{CH}_{4}$ & 0.080 \\
Total HC & 1700 \\
\hline
\end{tabular}


volume will be the same. Thus, as long as the air volume over which impacts are being averaged is considerably greater than the initial volume of the emitted aircraft contrails, the following results are invariant to the air volume considered.

Aircraft emissions include several chemicals, but only $\mathrm{NO}_{x}$ emissions are considered here. Both plume models assume that the initial $\mathrm{NO}_{x}$ emissions are $96 \% \mathrm{NO}$ and $4 \% \mathrm{NO}_{2}$ (Petry et al. 1998). Aircraft emissions of $\mathrm{CO}$ and hydrocarbon are small and have little impact on the upper tropospheric chemistry (Beck et al. 1990; Hayman and Markiewicz 1996).

The initial chemical conditions for the ambient environment in both plume models are listed in Table 2. Ambient chemical concentrations represent an approximate chemical steady state where chemical production and loss for most intermediate and longer-lived constituents are approximately balanced. These ambient chemical concentrations are typical in the upper troposphere according to numerous measurements (Aikin et al. 1987; Ray et al. 1992; Murphy et al. 1993; Weinheimer et al. 1994; Liu et al. 1996; Schultz et al. 1999).

Both models integrate the Stockwell chemical mechanism (Stockwell et al. 1990) forward in time. The gas phase chemistry contains 157 reactions among 63 species, including 42 organics. 21 photolysis rate coefficients are derived from a radiative transfer model and are a function of time, latitude and altitude. Diumally varying photolysis rates typical of springtime, upper troposphere $40^{\circ} \mathrm{N}$ conditions are used.

\section{RESULTS}

The following results compare the $\mathrm{O}_{3}$ perturbations due to aircraft emissions calculated by the instantly diluted plume and the more realistic growing plume cases. The $\mathrm{O}_{3}$ perturbations are averaged over simulation times corresponding to the approximate residence time of $\mathrm{O}_{3}$ and reactive $\mathrm{NO}_{\mathrm{y}}\left(\mathrm{NO}, \mathrm{NO}_{2}, \mathrm{HNO}_{3}, \mathrm{~N}_{2} \mathrm{O}_{5}\right.$, and $\left.\mathrm{PAN}\right)$ in the midlatitude upper roposphere. The residence time of $\mathrm{O}_{3}$ in the upper troposphere is mainly determined by chemical reactions and convective ansport, and the residence time due to both processes varies with season. $\mathrm{O}_{3}$ is chemically destroyed by photolysis in the presence of water vapor, and by reaction with $\mathrm{HO}_{2}$ and $\mathrm{HO}$. The chemical lifetime of $\mathrm{O}_{3}$ in the midlatitude upper troposphere is estimated to be approximately 40 days in summer and 300 days in winter (Schultz et al. 1999; Liu et al. 1987). The $\mathrm{O}_{3}$ lifetime due to convective transport is determined by the magnitude of the convective mass flux, which replaces the air in the upper troposphere with lower troposphere air. According to Costen et al. (1988) and Lin et al. (1996), the average convective mass flux into the atmospheric layer between $100 \mathrm{hPa}$ and $350 \mathrm{hPa}$ in midlatitudes is approximately 15 $\mathrm{hPa} /$ day in summer and $8 \mathrm{hPa}$ /day in winter. Therefore $\mathrm{O}_{3}$ lifetime in the midlatitude upper troposphere resulting from convective mixing is about 17 days in summer and 32 days in winter. Combining the lifetimes due to chemical reactions and convective transport, the $\mathrm{O}_{3}$ lifetime probably varies between approximately 12 days in summer and up to 30 days in winter in the midlatitude upper troposphere. This is only a rough estimate of the $\mathrm{O}_{3}$ lifetime in the midlatitude upper troposphere, as the actual $\mathrm{O}_{3}$ lifetime varies with time and location. Residence time of reactive $\mathrm{NO}_{y}$ in the upper troposphere is probably shorter than $\mathrm{O}_{3}$ lifetime since $\mathrm{HNO}_{3}$ is efficiently scavenged by precipitation forming in the upper troposphere. Estimates of 
scavenging lifetimes in the upper troposphere are highly uncertain and variable, but time scales for removal are probably in the range of 1-10 days. In the following studies, a 12-day simulation time is used.

\subsection{Time Evolution of $\mathrm{O}_{3}$ and $\mathrm{NO}_{x}$ in Both Plume Models}

Figure 6 compares the time evolution of the $\mathrm{O}_{3}$ concentrations in the two plume models for 12-days following emission. In Fig. 6, $\mathrm{O}_{3}$ concentration curves of four cases are shown: Case 1- the $\mathrm{O}_{3}$ concentration calculated assuming aircraft emissions are instantly diluted throughout the averaging volume; Case 2- the $\mathrm{O}_{3}$ concentration in the actual growing plume into which aircraft- $\mathrm{NO}_{x}$ are emitted; Case 3- the $\mathrm{O}_{3}$ concentration in the ambient environment surrounding the aircraft plumes (no aircraft emissions); and Case 4- the volume-weighted average of chemically distinct subregions of the growing plume model (i.e., the average of Cases 2 and 3). The volume fraction of the growing aircraft plume, which increases with time until it occupies the entire averaging volume, is also plotted in Fig. 6 . Figure 6 shows that it takes about three days for the 14 aircraft plumes to grow to the size of the air volume in which aircraft impacts are being estimated. This is faster than the time for an individual plume to grow to the size of this grid volume ( 10 days) due to the greater number of plumes occupying a proportionally larger volume together as discussed in Section 2.1. The simulation for the two plume models starts at 9 AM local time. Fig. 6 shows that there is slightly more $\mathrm{O}_{3}$ calculated in the air containing additional aircraft $\mathrm{NO}_{x}$ emissions (Case 1,2 and 4) than in the ambient air (Case 3). Ozone concentrations in the ambient air with no aircraft emissions only change by extremely small amounts during this 12-day period resulting from the fact that the chemical

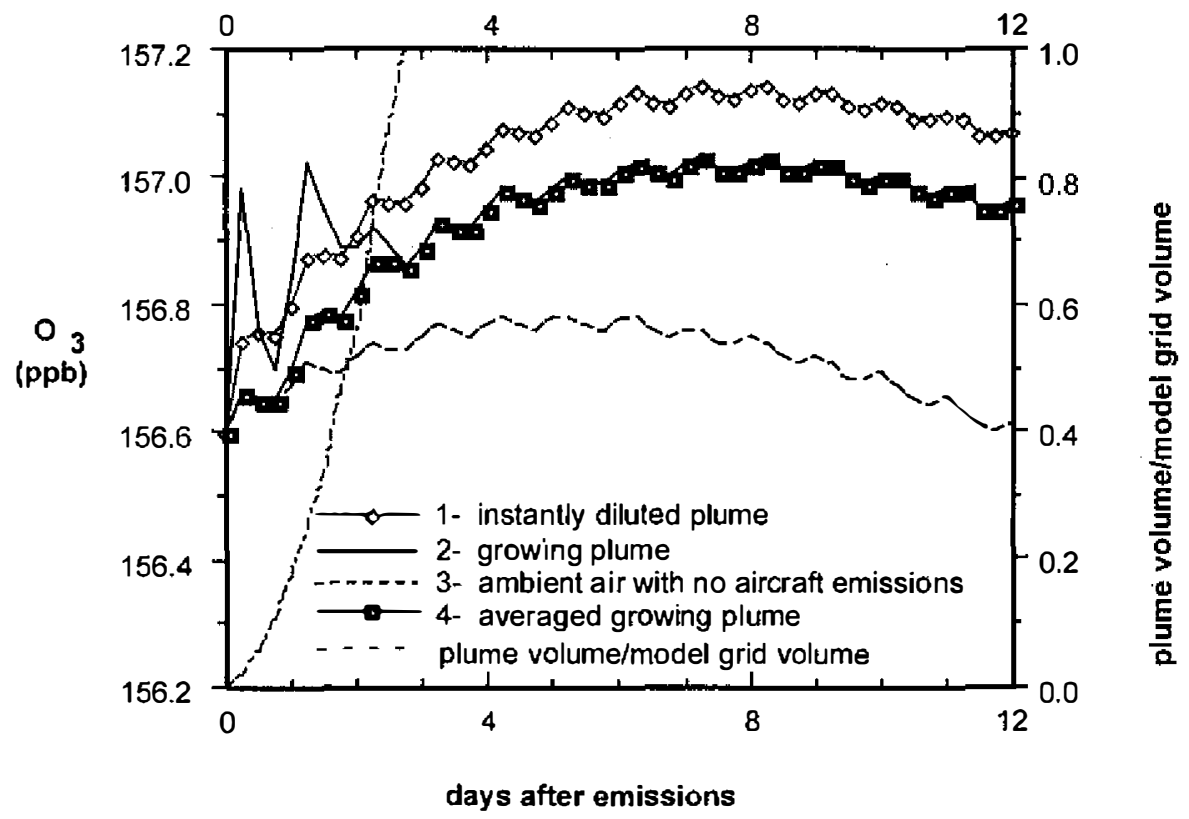

Fig. 6. Time evolution of the calculated $\mathrm{O}_{3}$ from the two plume model studies. 
conditions are close to a longer-term photochemical balance consistent with many upper tropospheric observations. With aircraft emissions immediately mixed to the ambient air, Case 1 shows that $\mathrm{O}_{3}$ concentrations increase by about $0.5 \mathrm{ppb}$ several days after emissions. In the entraining growing plume (Case 2) where $10 \mathrm{ppb}$ of initial $\mathrm{NO}_{\mathrm{x}}$ are added, the $\mathrm{O}_{3}$ concentration peaks after several hours as the added $\mathrm{NO}_{x}$ dramatically increases $\mathrm{O}_{3}$ concentrations. The peak $\mathrm{O}_{3}$ reoccurs around $3 \mathrm{PM}$ local time within the first three days until aircraft plumes grow to the size of the large scale model grid volume. As the aircraft plumes grow, ambient air with lower $\mathrm{O}_{3}$ and $\mathrm{NO}_{x}$ concentrations mixes into the plumes, lowering $\mathrm{O}_{3}$ concentrations, especially at night when no $\mathrm{O}_{3}$ is photochemically produced. As $\mathrm{NO}_{x}$ is converted to other nitrogen species, $\mathrm{O}_{3}$ concentrations in the entraining growing and instantly diluted plumes decrease slightly during the final several days of the simulation. During each day of the simulation, $\mathrm{O}_{3}$ concentrations vary slightly with a diurnal cycle. The concentration of $\mathrm{O}_{3}$ reaches a maximum in the afternoon each day as a result of photochemical production. The volume-weighted average of the growing plume model ( $\mathrm{Case} 4$ ) shows $\mathrm{O}_{3}$ concentrations close to ambient $\mathrm{O}_{3}$ concentrations in the beginning of the integration when the size of the entraining aircraft plumes is small. As the relative size of the growing plumes increases, the average $\mathrm{O}_{3}$ concentration over the larger grid volume containing the entraining growing plume is nudged to the $\mathrm{O}_{3}$ concentrations in the entraining growing plume itself. After about three days when the entraining plumes occupy the entire averaging volume, the averaged $\mathrm{O}_{3}$ concentration equals the $\mathrm{O}_{3}$ concentration in the entraining plumes. Comparing Case 4 with Case 1, Figure 6 shows that Case 4 calculates higher $\mathrm{O}_{3}$ concentrations than the more realistic growing plume at all times during the simulation. Thus, this case study shows that assuming instant dilution of aircraft emissions into a larger air volume typical of a global-scale model grid induces an overestimate in the calculated $\mathrm{O}_{3}$ perturbations.

Figure 7 shows the time evolution of calculated $\mathrm{NO}_{\mathrm{x}}$ of the four cases from the two plume models corresponding to Fig. 6. As shown in Fig. 7, $\mathrm{NO}_{\mathrm{x}}$ concentrations in the ambient air (Case 3) remain at an approximate steady state $38 \mathrm{ppt}$ throughout the simulation. In the instantly diluted plume (Case 1), Figure 7 shows that $\mathrm{NO}_{x}$ concentrations rapidly decrease during the first two or three days from initially about $51 \mathrm{ppt}$ to below $40 \mathrm{ppt}$ as the emitted $\mathrm{NO}_{\mathrm{x}}$ are converted to other $\mathrm{NO}_{y}$ species. By the end of the third day, the $\mathrm{NO}_{\mathrm{x}}$ concentrations in Case 1 reach an approximate steady state and concentrations only change slightly with time. Case 2 shows the $\mathrm{NO}_{\mathrm{x}}$ concentrations in the entraining growing plume where aircraft- $\mathrm{NO}_{\mathrm{x}}$ are emitted decreasing from $10 \mathrm{ppb}$ initially to about $38 \mathrm{ppt}$ within the first three days. In addition to the conversion of emitted $\mathrm{NO}_{x}$, the rapid decrease of $\mathrm{NO}_{x}$ concentrations in the entraining growing plume results from the dilution of the aircraft plumes with ambient air. After three days, the growing plumes have spread over the entire larger air volume, and the $\mathrm{NO}_{\mathrm{x}}$ concentrations thus equals the $\mathrm{NO}_{\mathrm{x}}$ concentrations in the averaged growing plume during the remaining simulation period. Case 4 shows that the averaged $\mathrm{NO}_{x}$ concentrations (volume weighted-average of Cases 2 and 3 ) in the growing plume model are slightly larger than in the instantly diluted model during the first one or two days, but the differences essentially disappear during the last 8-10 days. The slightly larger concentration of $\mathrm{NO}_{x}$ in the growing plume model can be attributed to slower $\mathrm{NO}_{\mathrm{x}}$ conversion in the initially small aircraft plumes before they expand to a certain size. 


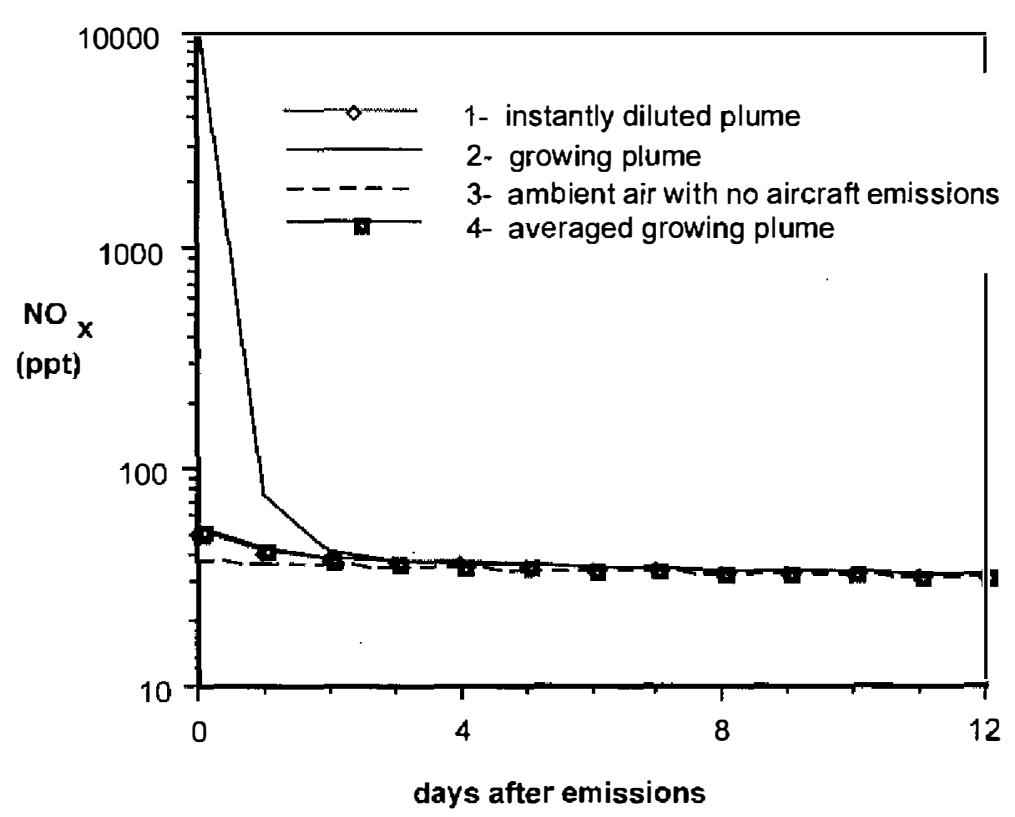

Fig. 7. Time evolution of the calculated $\mathrm{NO}_{\mathrm{x}}$ from the two plume model studies.

\subsection{Overestimate of $\mathrm{O}_{3}$ Impacts due to Assuming Instant Dilution of Aircraft Emissions}

To quantify the overestimated $\mathrm{O}_{3}$ impacts due to assuming instant dilution of aircraft emissions, it is convenient to define the $\mathrm{O}_{3}$ molecules generated per molecule of aircraft- $\mathrm{NO}_{x}$ emitted ( $\frac{\Delta O_{3}}{\Delta N O_{x}}$ ), which is often referred to as the "ozone production efficiency" (OPE).

$\mathrm{OPE}=\frac{\left(\mathrm{O}_{3} \text { concentration in either of the plume cases }-\mathrm{O}_{3} \text { concentration in the ambient air }\right)}{\mathrm{NO}_{\mathrm{x}} \text { concentration added to air volume }}$

Figure 8 shows $\mathrm{O}_{3}$ production per aircraft- $\mathrm{NO}_{x}$ emitted in the averaged growing plume (Case 4 in Fig. 6) and in the instantly diluted plume (Case 1 in Fig. 6). The OPE increases with time after emissions in both plume cases. In the averaged growing plume, the increase of OPE in the first day is small, with only about two additional molecules of $\mathrm{O}_{3}$ generated per molecule of $\mathrm{NO}_{x}$ emitted. In contrast, the instantly diluted plume calculates a rapid increase of up to about $10 \mathrm{ppb} \mathrm{O}_{3}$ per $\mathrm{ppb} \mathrm{NO}_{\mathrm{x}}$ emitted during the first day. In both plume simulations, the number of $\mathrm{O}_{3}$ molecules generated per molecule of $\mathrm{NO}_{x}$ emitted increases throughout the 12day simulation, after which 26-35 $\mathrm{ppb}_{3}$ is generated per $\mathrm{ppb} \mathrm{NO}_{\mathrm{x}}$ added to the upper troposphere. Therefore according to either model, $\mathrm{O}_{3}$ is continuously produced in the upper troposphere as additional $\mathrm{NO}_{x}$ are added. Over a wide range of environmental chemical conditions, each additional $\mathrm{ppb}$ of $\mathrm{NO}_{x}$ added to the upper troposphere induces an averaged net increase in $\mathrm{O}_{3}$ production of $2-3 \mathrm{ppb}$ per day as long as the additional $\mathrm{NO}_{\mathrm{y}}$ resides in the 


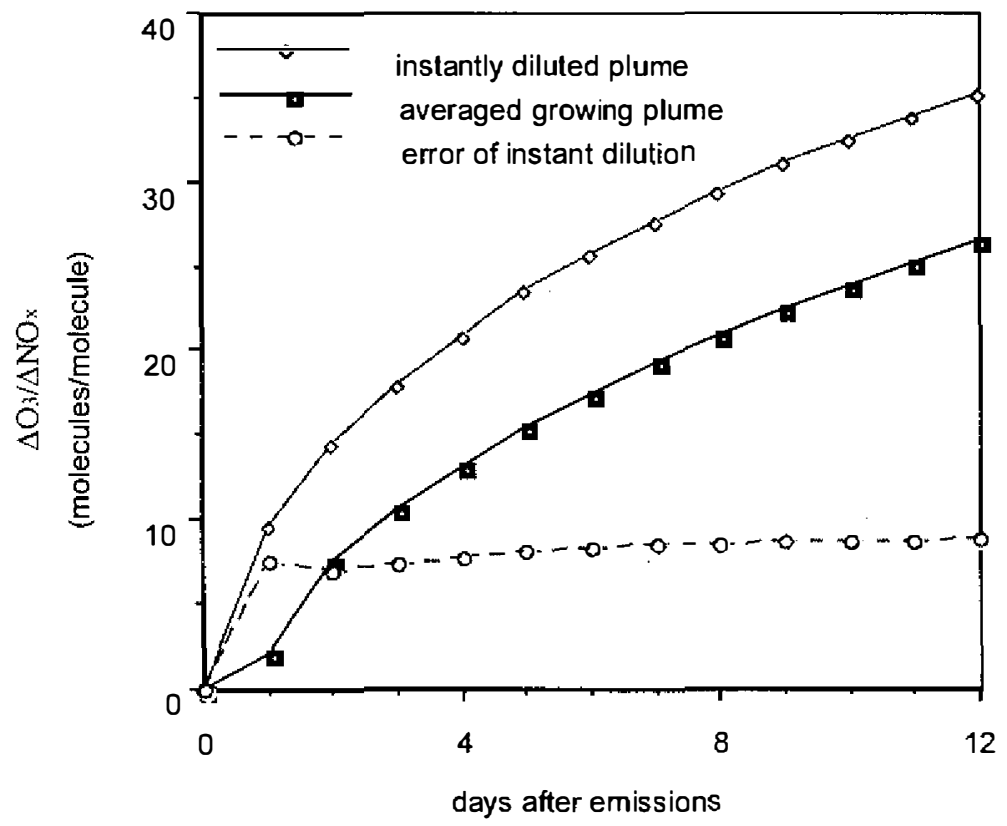

Fig. 8. Time evolution of $\mathrm{O}_{3}$ molecules generated per aircraft-emitted $\mathrm{NO}_{x}$ in the base case study.

upper troposphere. Thus, net ozone impacts are ultimately limited by the residence time of reactive $\mathrm{NO}_{\mathrm{y}}$ in the upper troposphere.

The different ozone production efficiency calculated by the two models shows that there is an appreciable overestimate of calculated $\mathrm{O}_{3}$ production if $\mathrm{NO}_{x}$ emissions are instantly diluted throughout a larger averaging volume. Furthermore, most of the difference in net ozone production occurs while the plumes are relatively small - i.e., during the first day or so following emissions. Then the overestimate of $\mathrm{O}_{3}$ production per $\mathrm{NO}_{x}$ emitted remains constant at around 8-9 $\mathrm{ppb} \mathrm{O}_{3}$ per ppb $\mathrm{NO}_{\mathrm{x}}$ at all times after the emissions are more or less uniformly mixed within the large-scale averaging volume. Under the conditions considered here, after 12 days $\mathrm{O}_{3}$ impacts are overestimated by $30 \%$ if emissions are added uniformly throughout grid volumes of air typical of the grid cells used by larger-scale chemical models of the atmosphere.

The overestimates of $\mathrm{O}_{3}$ production by assuming instant dilution of aircraft emissions result from the fact that the $\mathrm{O}_{3}$ formation rate is non-linearly related to $\mathrm{NO}_{x}$ concentrations. Higher $\mathrm{NO}_{x}$ concentrations in small initial aircraft plumes do not necessarily generate more $\mathrm{O}_{3}$ formation and may even decrease $\mathrm{O}_{3}$ formation. Figure 9 shows an example of the instantaneous ozone formation rates due to chemical processes at local noon as a function of ambient $\mathrm{NO}_{x}$ concentrations. In the calculation of the formation rates shown in Fig. 9, the other main species concentrations that are used are shown in Table 2. Figure 9 shows that the $\mathrm{O}_{3}$ formation rate increases with ambient $\mathrm{NO}_{\mathrm{x}}$ concentrations when $\mathrm{NO}_{\mathrm{x}}$ concentrations are low and that $\mathrm{O}_{3}$ formation occurs most rapidly when $\mathrm{NO}_{x}$ concentrations are between 0.1 to $1 \mathrm{ppb}$. When ambient $\mathrm{NO}_{x}$ concentrations are greater than $1 \mathrm{ppb}$, the $\mathrm{O}_{3}$ formation rate decreases with 


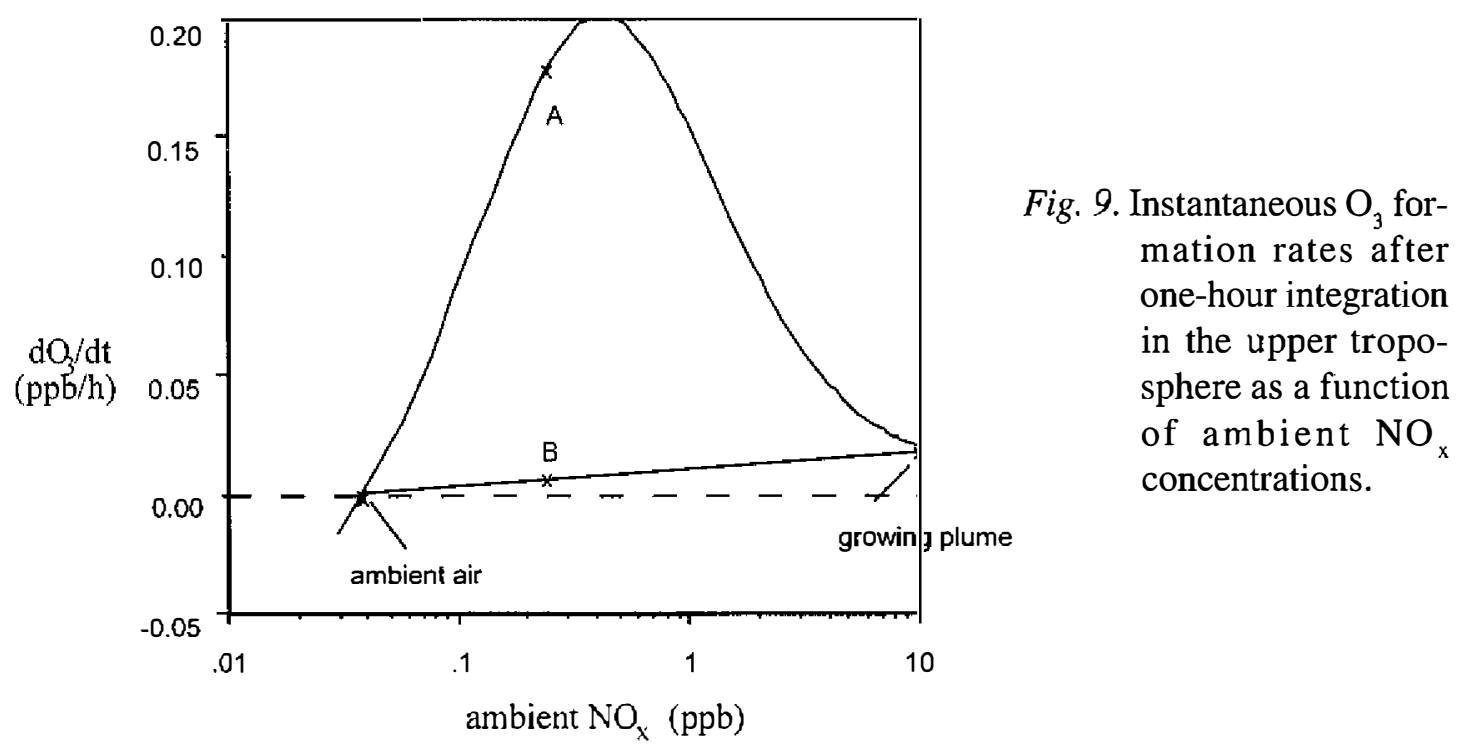

ambient $\mathrm{NO}_{\mathrm{x}}$ concentrations. Since $\mathrm{NO}_{\mathrm{x}}$ concentrations in initial aircraft contrails are about 10 ppb and the ambient $\mathrm{NO}_{\mathrm{x}}$ surrounding the aircraft plumes is considerably lower - $38 \mathrm{ppt}$ in these cases, the local $\mathrm{O}_{3}$ formation rates in both the plumes and ambient environment are close to zero. Thus, the averaged $\mathrm{O}_{3}$ formation rate in these two environments (point $\mathrm{B}$ in Fig. 9) is also close to zero. The averaged $\mathrm{NO}_{\mathrm{x}}$ concentration in the averaged growing plume (point $\mathrm{B}$ ) is proportional to the initial volume fraction occupied by the aircraft plumes inside the larger air volume. If more aircraft plumes are present in the larger air volume where aircraft impacts are considered, the averaged $\mathrm{NO}_{x}$ concentration is larger. In the instantly diluted emission case, the same amount of aircraft-NO $\mathrm{N}_{x}$ is spread over the larger air volume, and the $\mathrm{O}_{3}$ formation rate (point A in Fig. 9) calculated at the diluted $\mathrm{NO}_{x}$ concentrations follows the $\mathrm{O}_{3}$ formation rate vs. $\mathrm{NO}_{\mathrm{x}}$ curve and is considerably larger than zero. Therefore, under most conditions, artificially spreading $\mathrm{NO}_{x}$ emissions over a large volume of air leads to an overestimate of $\mathrm{O}_{3}$ production due to the nonlinearity of $\mathrm{O}_{3}$ formation rate vs. $\mathrm{NO}_{x}$ concentrations.

During the first day when the aircraft plumes are small, assuming instant dilution of aircraft emissions can create an appreciable overestimate of $\mathrm{O}_{3}$ formation due to this nonlinear relationship. After the first day, aircraft plumes become diluted with ambient air, and the production rate of $\mathrm{O}_{3}$ inside both plume models converges. However, the overestimated $\mathrm{O}_{3}$ production calculated during the first day is preserved and the absolute error is almost insensitive with time no matter how long the simulation period is after the first day or two following significant dilution.

\subsection{Sensitivity of Overestimate of OPE to Ambient Parameters}

The overestimate of $\mathrm{O}_{3}$ production per $\mathrm{NO}_{x}$ ernitted due to the assumption of instant dilution of aircraft emissions is a function of several environmental and model parameters. For 
example, $\mathrm{O}_{3}$ productions will vary in both plume models when the ambient $\mathrm{NO}_{\mathrm{x}}$ concentrations are different. The vertical diffusion coefficient and the vertical wind shear in the ambient air govern the growth rate of the aircraft plumes, and thus induce different $\mathrm{O}_{3}$ formation within the growing plume. Under these different ambient conditions, assuming instant dilution within a larger air volume can produce different overestimates of $\mathrm{O}_{3}$ production. In the following studies, the overestimate due to assuming instant dilution of aircraft emissions is calculated over a wide range of vertical wind shears, vertical diffusion coefficients, ambient $\mathrm{NO}_{x}$ concentrations, and ambient $\mathrm{O}_{3}$ concentrations. In each sensitivity study, only one factor is changed, while the other factors are set to values listed in Table 1, unless otherwise indicated.

Figure 10 shows the ozone production efficiency in the averaged growing plume, the instantly diluted plume, and the errors generated due to instant dilution of aircraft emissions after 12 days as a function of the vertical diffusion coefficient. The dotted lines in the middle of each figure (Figs. 10 to 13) mark the standard atmospheric conditions we chose for the base case studies and are the same conditions shown in Tables 1 and 2. As noted in Fig. 8, the error in OPE grows rapidly during the first day or two and then slowly levels off to an approximately constant value afterwards. Therefore, the errors generated at the end of the simulation period shown in Fig. 10 and in later figures are not sensitive to the simulation time. Figure 10 shows that in the instantly diluted plume, the calculated ozone production efficiency remains unchanged with vertical diffusion coefficient, while in the averaged growing plume the value increases with vertical diffusion coefficient, and thus the overestimate of ozone production efficiency decreases with increasing vertical diffusion coefficient. When vertical diffusion coefficient decreases to within the molecular diffusion range $\left(10^{-5}\right.$ to $\left.10^{-4} \mathrm{~m}^{2} / \mathrm{s}\right)$, about 20 more $\mathrm{O}_{3}$ molecules are calculated by the instantly diluted plume model than by the growing plume model for each $\mathrm{NO}_{x}$ emitted. This represents about a $100 \%$ error. When vertical diffusion coefficients are in the range of large turbulent diffusion, the overestimate of ozone production efficiency due to assuming aircraft emissions are instantly diluted to the ambient air is only about $2 \mathrm{ppb} \mathrm{O}_{3}$ per ppb $\mathrm{NO}_{x}$, a relatively small error of only $5 \%$. Aircraft plumes are more rapidly mixed into the larger air volume in high diffusing conditions. Under these conditions, the calculated ozone production efficiency from the growing plume case is closer to the ozone production efficiency calculated assuming instant mixing. While large upper tropospheric turbulence is relatively rare, under typical upper tropospheric conditions, vertical diff usion coefficients are probably in the range of molecular to small turbulent diffusion $\left(10^{-4}-10^{-1} \mathrm{~m}^{2} \mathrm{~s}^{-1}\right)$, with the overestimate of ozone production efficiency at about $8 \mathrm{ppb} \mathrm{O}_{3}$ per ppb $\mathrm{NO}_{x}$ as shown in the base case study. This corresponds to about a $30 \%$ error.

Figure 11 shows the net effective error of calculated ozone production efficiency as a function of vertical wind shear. When the vertical wind shear is extremely small, $\mathrm{O}_{3}$ production is overestimated by about $15 \mathrm{O}_{3}$ molecules per aircraft- $\mathrm{NO}_{\mathrm{x}}$ emitted, whereas with strong wind shear conditions there is almost no overestimate because of rapid shear-induced mixing. The error is almost insensitive to wind shear under extremely low wind shear conditions as the overestimated $\mathrm{O}_{3}$ production per $\mathrm{NO}_{x}$ remains about $15 \mathrm{O}_{3}$ molecules per aircraft-emitted $\mathrm{NO}_{x}$. Under typical atmospheric conditions, absolute vertical wind shear ranges from $10^{-3}$ to $10^{-2} \mathrm{~s}^{-1}$, while the component of shear perpendicular to the plume axis can be much smaller, and thus the overestimated $\mathrm{O}_{3}$ production can be larger than the typical conditions shown in Fig. 8 . 


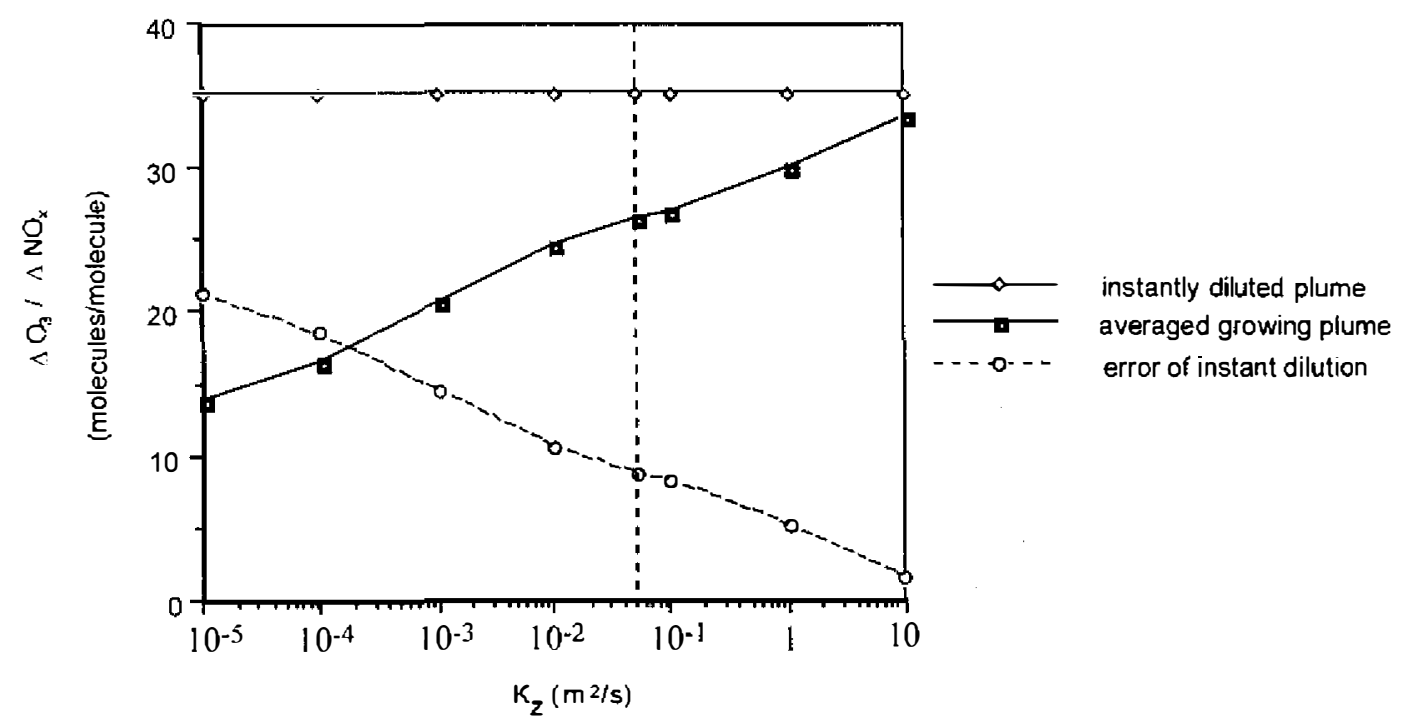

Fig. 10. $\mathrm{O}_{3}$ molecules generated per molecule of aircraft-emitted $\mathrm{NO}_{x}$ calculated from the two plume models as a function of upper tropospheric vertical diffusion coefficient, $\mathrm{K}_{\mathrm{z}}$.

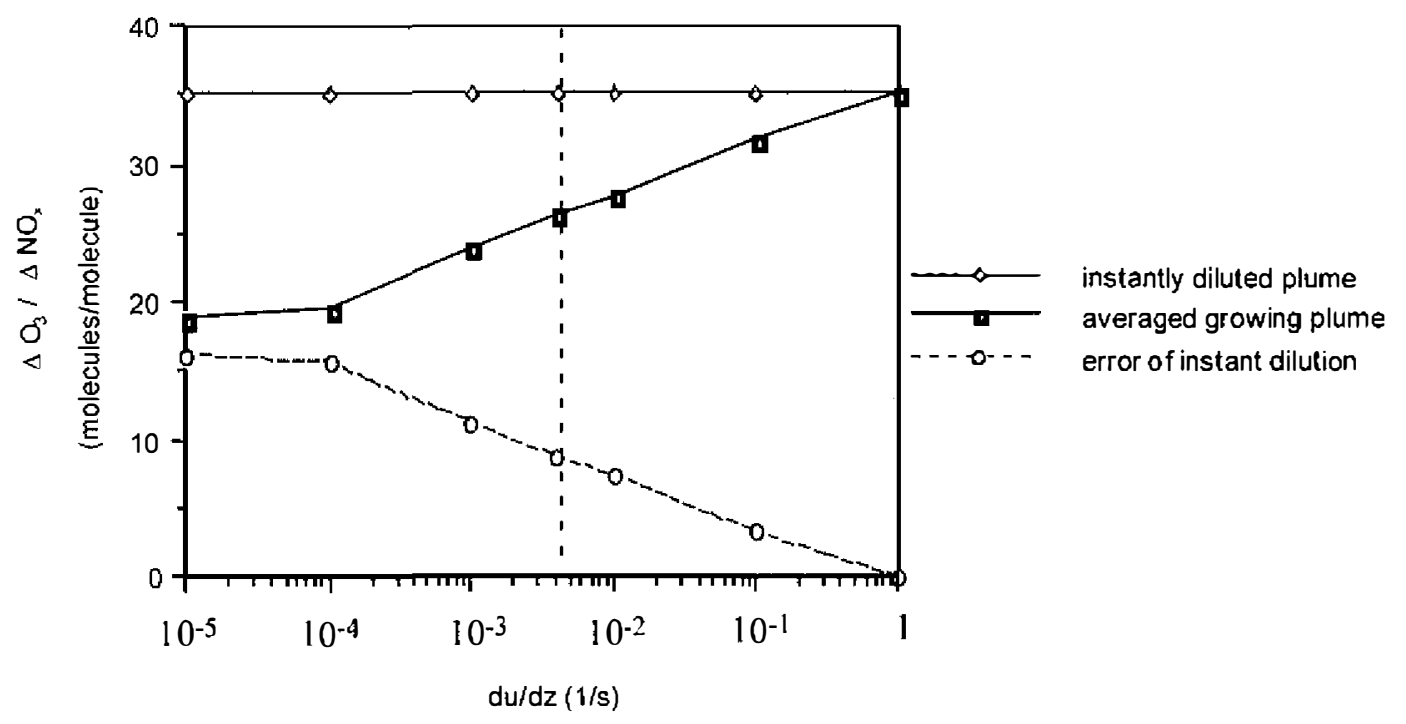

Fig. 11. Same as in Fig. 10, but as a function of vertical wind shear, $\Delta \mathrm{u} / \Delta \mathrm{z}$.

Figure 12 presents the overestimate of ozone production efficiency generated by assuming instant mixing of aircraft emissions as a function of ambient $\mathrm{NO}_{\mathrm{x}}$ concentrations, while maintaining ambient $\mathrm{NO}_{x}, \mathrm{NO}_{y}$ and $\mathrm{O}_{3}$ concentrations at an approximate chemical steady state. It can be seen that the ozone production efficiency in both plume cases decreases with ambient 


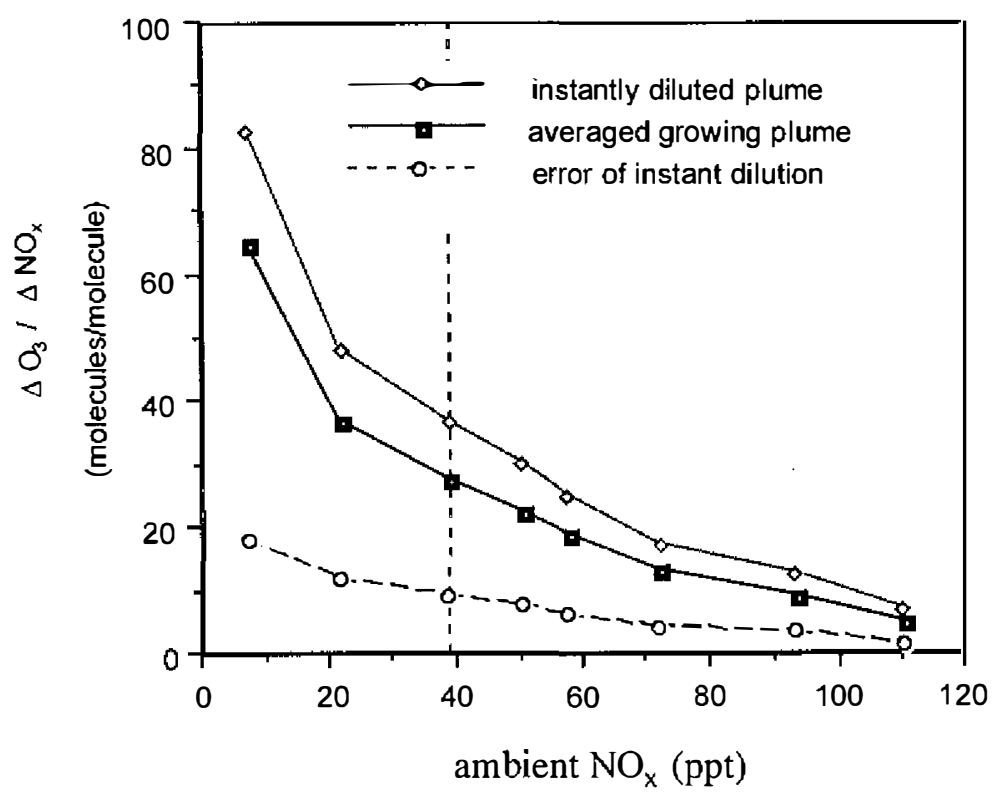

Fig. 12. Same as in Fig. 10, but as a function of ambient $\mathrm{NO}_{x}$ concentrations.

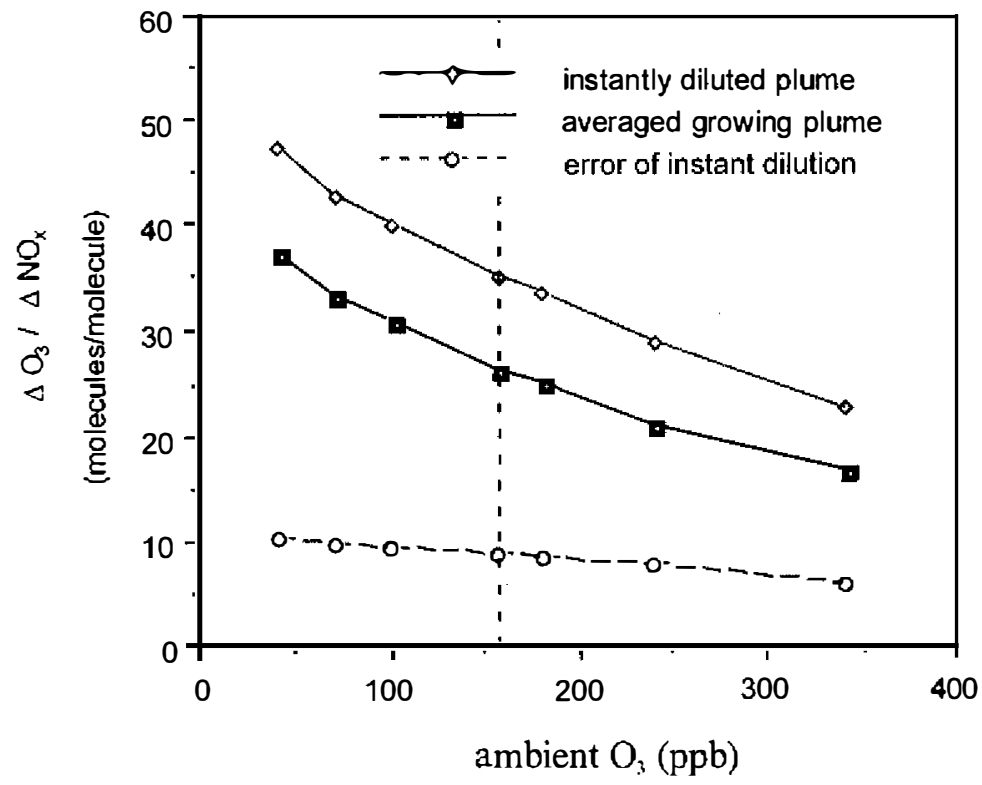

Fig. 13. Same as in Fig. 10, but as a function of ambient $\mathrm{O}_{3}$ concentrations.

$\mathrm{NO}_{x}$ concentrations, and with the same amount of $\mathrm{NO}_{x}$ emissions, the enhancement of $\mathrm{O}_{3}$ formation rate is lower in ambient conditions containing high $\mathrm{NO}_{\mathrm{x}}$ concentrations (Liu et al. 1987; Schumann 1997; Tsai 1999). Thus, the absolute overestimate of $\mathrm{O}_{3}$ production per $\mathrm{NO}_{x}$ 
also decreases. When ambient $\mathrm{NO}_{x}$ is about $10 \mathrm{ppt}$, about 18 more $\mathrm{O}_{3}$ molecules are calculated in the instantly diluted plume for each aircraft- $\mathrm{NO}_{x}$ emitted. If ambient $\mathrm{NO}_{x}$ approaches 110 ppt, only about 2 more $\mathrm{O}_{3}$ molecules are calculated in the instantly diluted plume for each aircraft- $\mathrm{NO}_{x}$ emitted. Hence; there is a greater absolute error of calculated $\mathrm{O}_{3}$ production in low $\mathrm{NO}_{\mathrm{x}}$ environments than in high $\mathrm{NO}_{x}$ environments, although the relative error is always about $30 \%$ under any ambient $\mathrm{NO}_{x}$ condition.

Ambient $\mathrm{O}_{3}$ concentrations will also influence $\mathrm{O}_{3}$ production and thus the error inherent in calculated $\mathrm{O}_{3}$ perturbations by assuming instant dilution of emitted $\mathrm{NO}_{x}$. In the above $\mathrm{NO}_{x}$ sensitivity study, ambient $\mathrm{NO}_{x}, \mathrm{NO}_{y}$, and $\mathrm{O}_{3}$ concentrations are all changed in an approximately photochemical consistent manner. In order to estimate the calculated $\mathrm{O}_{3}$ production due to any change in ambient $\mathrm{O}_{3}$ concentrations alone, the concentration of $\mathrm{O}_{3}$ is changed in this sensitivity study, while the ambient $\mathrm{NO}_{x}, \mathrm{NO}_{y}$ and other species remain the same as in the base case.

Figure 13 shows the calculated $\mathrm{O}_{3}$ production efficiency in both plume models as a function of ambient $\mathrm{O}_{3}$ concentrations. It can be seen that the $\mathrm{O}_{3}$ production per $\mathrm{NO}_{x}$ emitted decreases with ambient $\mathrm{O}_{3}$ concentrations in both plume models. More than 40 molecules of $\mathrm{O}_{3}$ are calculated per molecule of $\mathrm{NO}_{x}$ added according to the instantly diluted plume model when ambient $\mathrm{O}_{3}$ is less than $100 \mathrm{ppb}$. If ambient $\mathrm{O}_{3}$ is greater than $300 \mathrm{ppb}$, the $\mathrm{O}_{3}$ production per $\mathrm{NO}_{x}$ decreases by nearly a factor of two. In the more realistic growing plume model, $\mathrm{O}_{3}$ production is about $25 \%$ less than that calculated from the instant dilution model, over all $\mathrm{O}_{3}$ concentration ranges. The changes of $\mathrm{O}_{3}$ production per $\mathrm{NO}_{x}$ with ambient $\mathrm{O}_{3}$ concentrations are smaller than the changes with ambient $\mathrm{NO}_{x}$ concentrations according to both plume models. Figure 12 shows that the $\mathrm{O}_{3}$ production per $\mathrm{NO}_{x}$ emitted can vary by a factor of 8 in both plume models due to changing ambient $\mathrm{NO}_{x}, \mathrm{NO}_{y}$ and $\mathrm{O}_{3}$ from low to high concentrations. This sensitivity study shows that changing the ambient $\mathrm{O}_{3}$ concentrations alone within the same ranges only accounts for a factor of 2 of these changes. The overestimated $\mathrm{O}_{3}$ production resulting from these smaller changes of $\mathrm{O}_{3}$ production is also smaller. Figure 13 shows that the error of calculated $\mathrm{O}_{3}$ perturbation remains at 6 - 10 molecules of $\mathrm{O}_{3}$ per added molecule of added $\mathrm{NO}_{x}$ over a wide range of $\mathrm{O}_{3}$ concentrations.

\section{COMPENSATING FOR SUB-GRID SCALE CHEMICAL INHOMOGENEITIES IN LARGE-SCALE MODELS}

The results presented in the previous section demonstrate that under typical conditions, appreciable overestimates (about 30\%) can be made in calculating aircraft impacts on $\mathrm{O}_{3}$ if subgrid-scale $\mathrm{NO}_{x}$ concentrations distributions are not accounted for. Downwind of major flight corridors, aircraft plumes take up to several days to diffuse slowly to the size of air volumes typical of larger-scale Eulerian models used to assess aircraft impacts. If these aircraft emissions are assumed to be instantly diffused throughout a large air volume, ozone production will be overestimated due to the nonlinear relationship between ozone production and $\mathrm{NO}_{\mathrm{x}}$ concentrations. Thus, the implicit instant dilution of aircraft- $\mathrm{NO}_{\mathrm{x}}$ over grid volumes of global-scale GCMs probably leads to appreciable overestimates in calculated $\mathrm{O}_{3}$ impacts. 
The problem of artificially diffusing $\mathrm{NO}_{\mathrm{x}}$ emissions into relatively large GCM grid volumes has been recognized in previous studies of tropospheric chemistry (e.g., Chatfield and Delany 1990). Several different approaches have been proposed to alleviate this error. In order to reduce the $\mathrm{O}_{3}$ production overestimate in the lower troposphere downwind of power plants and small urban areas, Sillman et al. (1990a, 1990b) divided each regional scale model grid into several subregions depending on the magnitude of emissions to account for the smaller scale plumes. In their regional scale model, $\mathrm{NO}_{x}$ pollutants were emitted into a relatively small "urban plume" section of each model grid. The size of the "urban plume" was calculated from average turbulence and wind speed conditions of the large cell into which emissions were occurring. The chemistry for each individual subregion of the model grid was calculated in addition to the mixing between the subregion and the remaining grid volume, which was parameterized in terms of wind speed and turbulent conditions. In another lower tropospheric application, Pleim et al. (1991) and Jang et al. (1995) employed a nested grid in which a higher model resolution was used in high emissions regions of the simulation domain. In an analysis of upper roposphere aircraft emissions, Petry et al. (1998) compensated for the inherent overestimate by adding a "negative $\mathrm{O}_{3}$ emission" whenever aircraft $\mathrm{NO}_{x}$ emissions were occurring. The exact amount of $\mathrm{O}_{3}$ removed was empirically quantified so as to compensate for the known overestimate inherent by artificially diffusing aircraft $\mathrm{NO}_{x}$ emissions. Some of these methods for mitigating this error entail considerable increase in computational resources, which may not be feasible to implement in global-scale multi-year studies of ropospheric chemistry. The method of Petry et al., while simple, could potentially produce biases in calculated $\mathrm{O}_{3}$ impacts since, as previously shown here, the error on ozone takes several days to appear.

Here, a simple method is suggested to "slow down" the $\mathrm{O}_{3}$ formation rate in regions where aircraft- $\mathrm{NO}_{x}$ emissions are known to be present in the atmosphere in unresolved plumes. The method suggested here involves adjusting a key $\mathrm{O}_{3}$ formation reaction coefficient in a large-scale model in a manner which can approximately compensate for the inherent overestimate error induced by neglecting plume growth.

\subsection{Method of Adjustment}

The major reactions for $\mathrm{O}_{3}$ formation in the troposphere are through $\mathrm{NO}_{2}$ photolysis:

$$
\begin{gathered}
\mathrm{NO}_{2}+\mathrm{hv} \rightarrow \mathrm{NO}+\mathrm{O}\left({ }^{3} \mathrm{P}\right), \\
\mathrm{O}\left({ }^{3} \mathrm{P}\right)+\mathrm{O}_{2}+\mathrm{M} \rightarrow \mathrm{O}_{3}+\mathrm{M} .
\end{gathered}
$$

$\mathrm{M}$ in Reaction (9) is a molecule that absorbs the excess energy of the $\mathrm{O}$ atoms and stabilizes the final products. Once formed, $\mathrm{O}_{3}$ reacts rapidly with $\mathrm{NO}$ to regenerate $\mathrm{NO}_{2}$ via

$$
\mathrm{NO}+\mathrm{O}_{3} \rightarrow \mathrm{NO}_{2}+\mathrm{O}_{2}
$$

Reactions (8) to (10) occur rapidly during the daytime, and $\mathrm{O}_{3}$ formed through Reaction (9) is almost balanced by $\mathrm{O}_{3}$ destruction by Reaction (10). Other reactions in the atmosphere gener- 
ate or destroy $\mathrm{O}_{3}$, but their reaction rates during the daytime are considerably slower than Reactions (8) to (10). Thus, in a first order approximation, the net $\mathrm{O}_{3}$ formation rate may be written as:

$$
\frac{d O_{3}}{d t}=\mathrm{J}_{8}\left[\mathrm{NO}_{2}\right]-\mathrm{K}_{10}[\mathrm{NO}]\left[\mathrm{O}_{3}\right]
$$

where $\mathrm{J}_{8}$ is the photolysis rate constant of Reaction (8) and $\mathrm{K}_{10}$ is the rate coefficient of Reaction (10). If the $\mathrm{O}_{3}$ formed through Reactions (8) to (9) is balanced by the $\mathrm{O}_{3}$ destroyed by (10), no net $\mathrm{O}_{3}$ is formed, and $\mathrm{dO}_{3} / \mathrm{dt}$ is approximately zero. However, a small fraction of NO may react with $\mathrm{HO}_{2}$ or other organic radicals to generate $\mathrm{NO}_{2}$ :

$$
\mathrm{NO}+\mathrm{HO}_{2} \rightarrow \mathrm{NO}_{2}+\mathrm{OH}
$$

The $\mathrm{OH}$ produced by Reaction (12) reacts with $\mathrm{VOCs}$, methane and $\mathrm{CO}$ and regenerates $\mathrm{HO}_{2}$. Therefore, in the presence of $\mathrm{CH}_{4}, \mathrm{CO}$, and VOCs, $\mathrm{NO}_{2}$ can be regenerated by Reaction (12) without consuming $\mathrm{O}_{3}$, thereby producing net $\mathrm{O}_{3}$. Hence, as noted by Thompson (1984), the net $\mathrm{O}_{3}$ formation rate is largely determined by the speed of Reaction (12). When the reaction rate of $\mathrm{NO}$ with $\mathrm{HO}_{2}$ is large, more $\mathrm{O}_{3}$ is formed. The net $\mathrm{O}_{3}$ formation rate can be simplified as:

$$
\frac{d O_{3}}{d t}=\mathrm{K}_{\mathrm{r} 2}[\mathrm{NO}]\left[\mathrm{HO}_{2}\right]
$$

where $\mathrm{K}_{\mathrm{i} 2}$ is the reaction coefficient for Reaction (12). Other reactions of organic hydroxyl radicals also convert $\mathrm{NO}$ to $\mathrm{NO}_{2}$ and therefore influence $\mathrm{O}_{3}$ formation, but these reactions are only significant when hydrocarbon concentrations are relatively high. In the upper troposphere where the concentrations of hydrocarbon are smaller than in the lower troposphere, the reactions of NO with organic hydroxyl radicals are not typically important relative to Reaction (12).

Since the $\mathrm{O}_{3}$ formation rate is proportional to the reaction coefficient $\mathrm{K}_{12}$, the method suggests here for lowering $\mathrm{O}_{3}$ formation in a diluted plume is to reduce the reaction rate coefficient $\mathrm{K}_{12}$. By reducing the reaction rate of this single equation, the "effective" ozone formation rate in the diluted plume can be adjusted to match the $\mathrm{O}_{3}$ generated in the growing plume.

\subsection{Empirical Reduction of Reaction Coefficient $K_{12}$}

To reduce the $\mathrm{O}_{3}$ formation in a model where aircraft $\mathrm{NO}_{x}$ emissions are unrealistically uniformly dispersed, the reaction coefficient of Reaction (12) is reduced to slow ozone formation. By multiplying $\mathrm{K}_{12}$ by a reduction factor, $\mathrm{O}_{3}$ production in the instantly diluted plume model can be adjusted so as to minimize the differences between $\mathrm{O}_{3}$ production calculated using the more realistic growing plume model and ozone formation calculated in a uniformly dispersed $\mathrm{NO}_{x}$ environment. The optimum reduction factor can be chosen by first calculating the $\mathrm{O}_{3}$ production difference between the two plume models over the 12-day period:

$$
\text { Diff }=\sum_{\text {time }=1 \text { day }}^{12 \text { days }}\left(O_{3 d}-O_{3 g}\right)^{2}
$$


where $\mathrm{O}_{3 \mathrm{~d}}$ and $\mathrm{O}_{3 \mathrm{~g}}$ are the $\mathrm{O}_{3}$ concentrations in the instantly diluted plume and the growing plume at each time step during the 12 -day period.

To select the optimum reduction factor during the 12-day period, $\mathrm{K}_{12}$ in the instantly diluted plume model is reduced in order to yield minimum differences with the more accurately calculated $\mathrm{O}_{3}$ concentrations in the growing plume model during the simulation period. The optimum reduction factor will be a function of integration time as the $\mathrm{O}_{3}$ production difference between the two plume models varies with time. In this study, the integration time will be the approximate residence time of $\mathrm{O}_{3}$ in the upper troposphere which, as discussed in Section 4 , is normally about 12 days.

\subsection{Result of Reducing Reaction Coefficient (12)}

Figure 14 shows the base case OPE as shown in Fig. 8, although additional calculations are performed using the instantly mixed model with different downward adjustments of the $\mathrm{HO}_{2}+\mathrm{NO}$ reaction coefficient $\left(\mathrm{K}_{12}\right)$. It is evident that the $\mathrm{O}_{3}$ productions per $\mathrm{NO}_{\mathrm{x}}$ emitted calculated using the instantly diluted plume model are larger than the $\mathrm{O}_{3}$ productions per $\mathrm{NO}_{x}$ emitted calculated by the growing plume model during the simulation period. If the $\mathrm{O}_{3}$ productions per $\mathrm{NO}_{\mathrm{x}}$ emitted in the instantly diluted plume are adjusted to match the first day value in the averaged growing plume, then $\mathrm{K}_{12}$ should be multiplied by a factor, $f$, of 0.877 . Figure 14 shows that $\mathrm{O}_{3}$ productions are appreciably suppressed in this case, and $\mathrm{O}_{3}$ concentrations can be reduced to fall below ambient concentrations even when $\mathrm{NO}_{x}$ is added. The behavior reflects the relatively strong sensitivity of $\mathrm{O}_{3}$ formation to this reaction. In contrast, a reduction

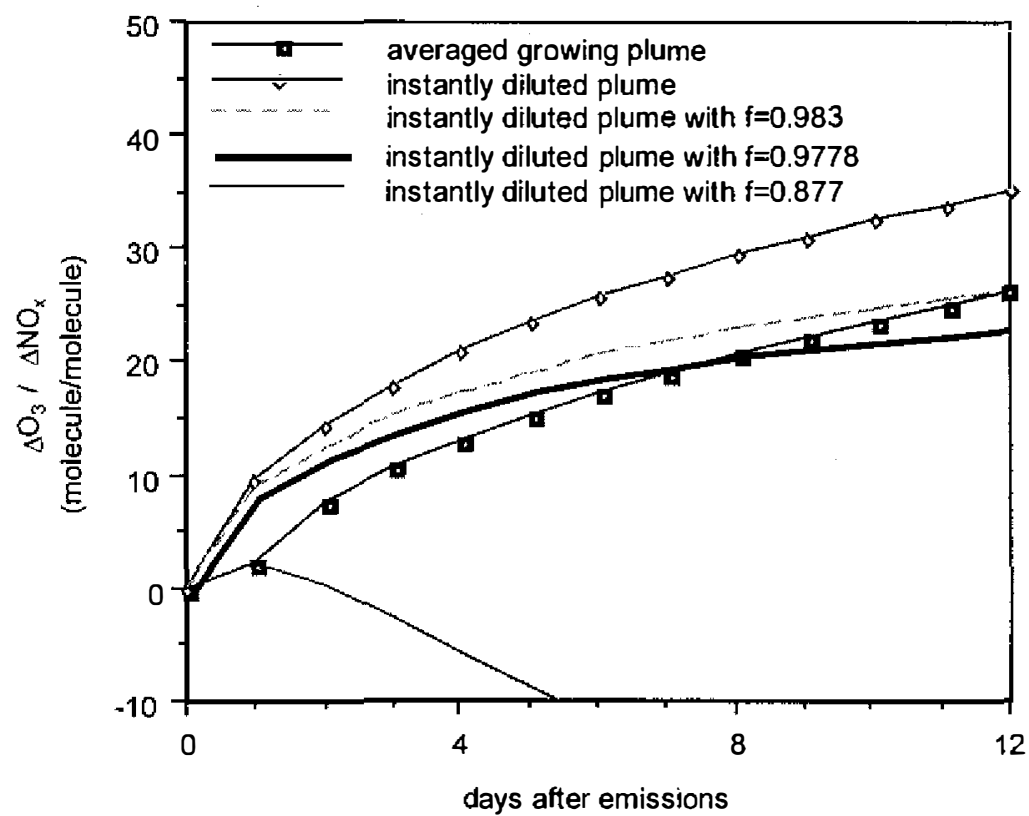

Fig. 14. $\Delta \mathrm{O}_{3} / \Delta \mathrm{NO}_{\mathrm{x}}$ calculated from the two plume models and the instantly diluted plume model with reaction coefficient $\mathrm{K}_{12}$ adjusted by constant $f$. 
of only $1.7 \%$ is needed to adjust the $\mathrm{O}_{3}$ productions in the instantly diluted plume, so the results match the $\mathrm{O}_{3}$ production in the growing plume on the last day.

Figure 15 shows the differences (Eq. 14) in $\mathrm{O}_{3}$ production between the two plume models over the simulation period as a function of the adjustment factor. Although adjustment factors of 0.877 and 0.983 reduce $\mathrm{O}_{3}$ productions in the instantly diluted plume and match the values in the growing plume on the first and last days, Figure 15 indicates that the $\mathrm{O}_{3}$ error due to instant dilution does not reach the minimum. After summing the difference of $\mathrm{O}_{3}$ productions over the simulation period, Figure 15 shows that the optimum adjustment factor of about 0 . 9778 yields the smallest differences between the "adjusted" instantly diluted plume model and the more realistic growing plume model.

Figure 14 shows that by multiplying $\mathrm{K}_{12}$ by an optimal $0.9778, \mathrm{O}_{3}$ production per $\mathrm{NO}_{x}$ emitted calculated by the instantly diluted model agrees much better with the more accurate growing plume model. In this iterative manner, the optimum factor under different atmospheric and model parameters condition can be estimated.

\subsection{Effect of Adjustment on Other Constituent Concentrations}

When adjusting the reaction coefficient to account for subgrid chemical effects, it is possible that concentration of other species will be perturbed in undesirable manners. Figure 16 shows the $\mathrm{NO}_{x}$ concentrations in the instantly diluted plume and the adjusted instantly diluted plume compared to the concentrations in the more accurate averaged growing plume. Clearly, $\mathrm{NO}_{x}$ concentrations in the growing plume and the instantly diluted plume decrease with time as $\mathrm{NO}_{\mathrm{x}}$ are converted to other reactive nitrogen species, and the $\mathrm{NO}_{\mathrm{x}}$ in the instantly diluted plume before and after adjustment remains almost the same. NO concentrations should increase and $\mathrm{NO}_{2}$ concentrations should decrease in response to reducing the reaction coefficient (12). However, Reaction (12) is slow compared to Reactions (8) and (10) in $\mathrm{NO}$ and $\mathrm{NO}_{2}$

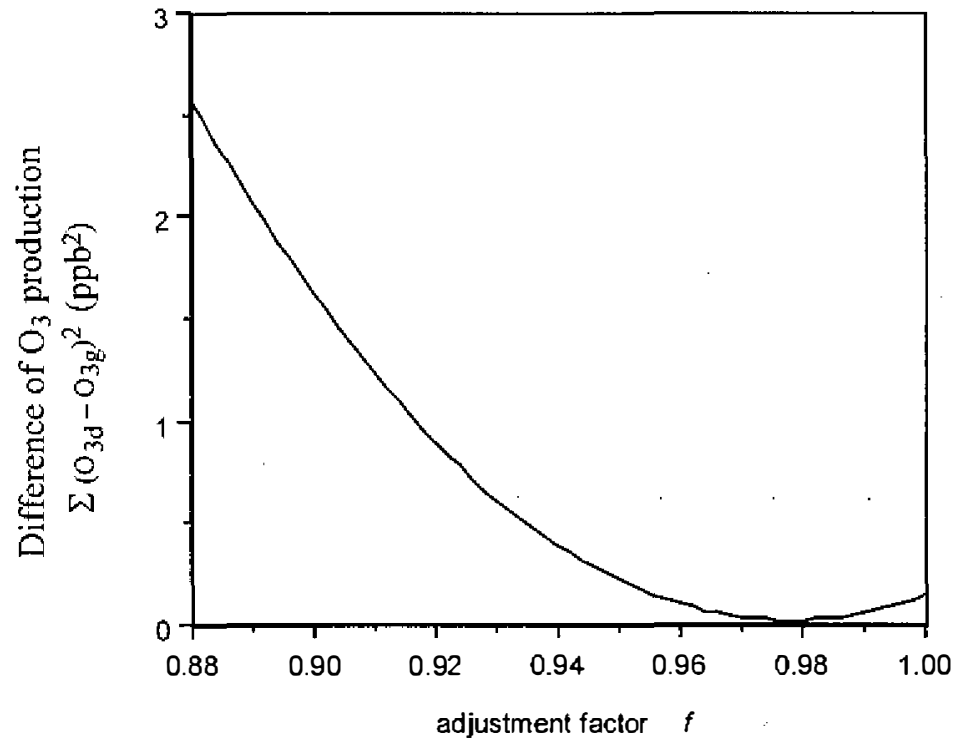

Fig. 15. Difference in $\mathrm{O}_{3}$ production between the two plume models over a 12-day period as a function of the adjustment factor. 


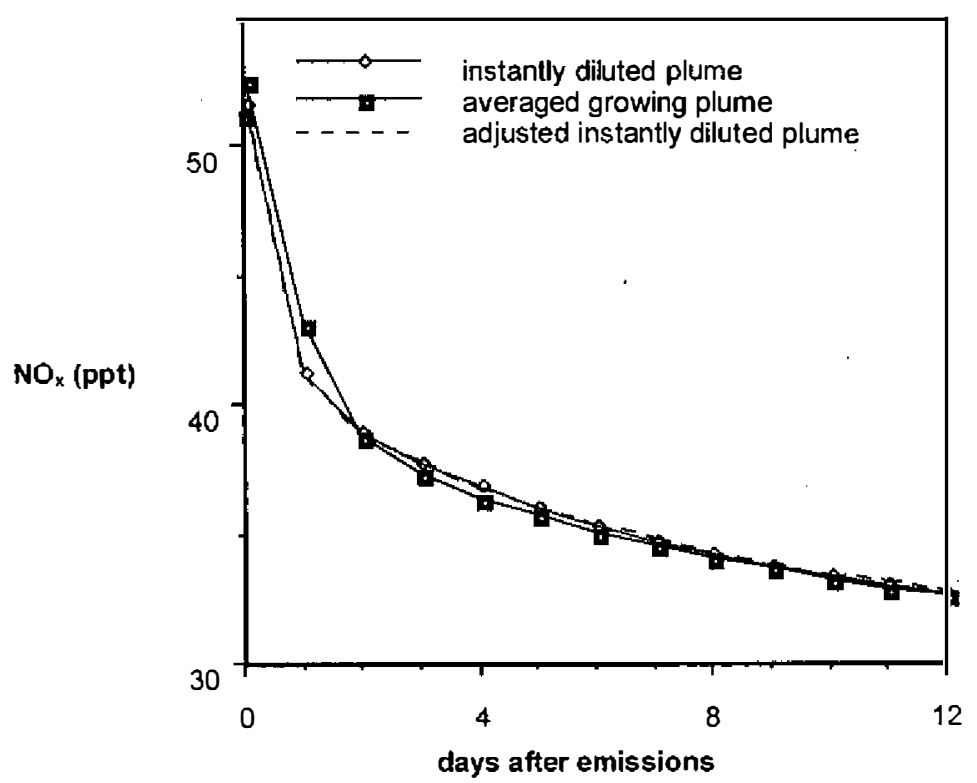

Fig. 16. Concentration of $\mathrm{NO}_{x}$ calculated from the two original plume models and the instantly diluted plume model with reaction coefficient $\mathrm{K}_{12}$ adjusted by $f=0.9778$.

reactions. Adjusting the reaction coefficient (12) by 2-3\% induces negligible changes in the concentrations of both $\mathrm{NO}$ and $\mathrm{NO}_{2}$, and thus $\mathrm{NO}_{x}$ concentrations remain almost unchanged.

$\mathrm{HO}$ is a very important oxidant in the troposphere and its concentration is also affected by Reaction (12). Reducing the reaction coefficient (12) should decrease the chemical production of $\mathrm{HO}$, thereby decreasing the concentration of $\mathrm{OH}$. However, reactions of other constituents, such as $\mathrm{O}_{3}, \mathrm{NO}_{2}, \mathrm{HCHO}$, and $\mathrm{CO}$ are also involved in $\mathrm{HO}$ production and loss, and these species are either directly or indirectly affected by Reaction (12) and can feedback to the HO concentration. Figure 17 shows that $\mathrm{HO}$ concentrations are slightly reduced in the instantly diluted plume after $\mathrm{K}_{12}$ is reduced. In Fig. 17, the large change in $\mathrm{HO}$ in the beginning of the both plume model simulations is due to adding aircraft $\mathrm{NO}_{\mathrm{x}}$ emissions, which perturbs the background $\mathrm{HO}$ concentrations. Based on these comparisons and additional comparisons within other constituent concentrations (not shown), it is concluded that a minor adjustment of $\mathrm{K}_{12}$ induces negligible changes in other species concentrations, but $\mathrm{O}_{3}$ perturbations calculated with the adjusted chemical reactions are closer to more accurate growing plume calculations.

\section{CONCLUSIONS}

A Lagrangian plume chemistry model has been used to estimate the potentially significant errors of calculated aircraft impacts that are inherent in larger-scale simulations of aircraft chemical impacts. Realistic aircraft plumes grow slowly in the initial few hours to day after emission, and the emitted aircraft pollutants remain confined to relatively small plume vol- 


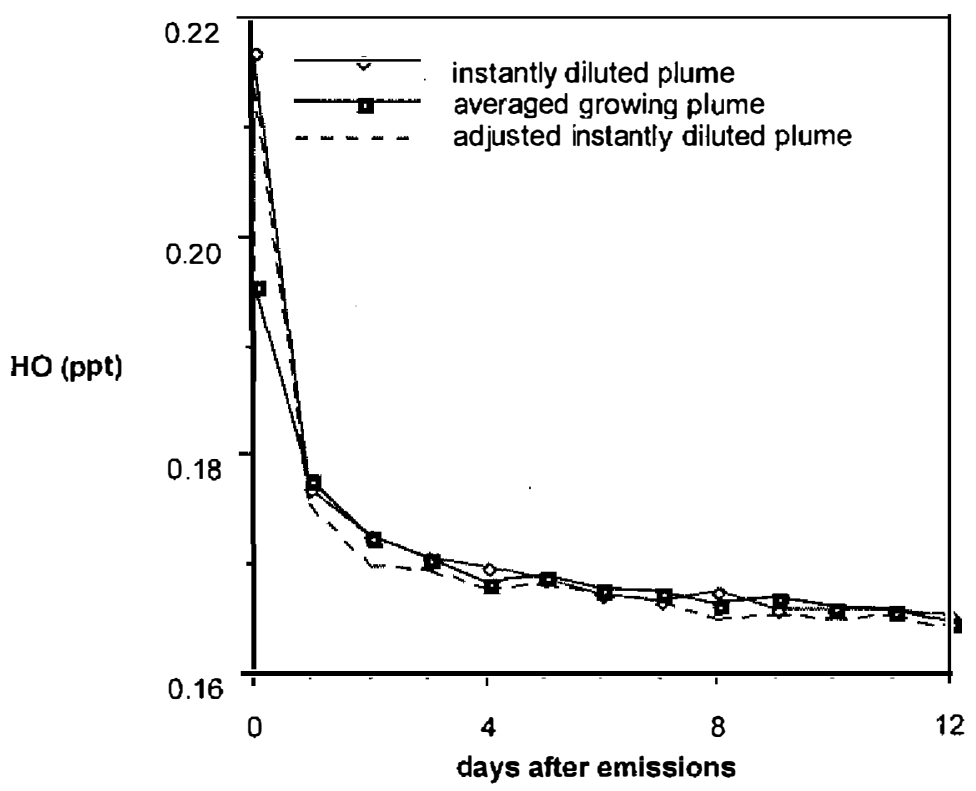

Fig. 17. Concentration of $\mathrm{HO}$ calculated from the two original plume models and the instantly diluted plume model with reaction coefficient $\mathrm{K}_{12}$ adjusted by $f=0.9778$.

umes where emitted $\mathrm{NO}_{x}$ concentrations are high, and little $\mathrm{O}_{3}$ is produced. Under shear and turbulent conditions typical of the upper troposphere, it takes several days for aircraft plumes to diffuse to a size comparable to the grid volume used by global-scale Eulerian models. By assuming aircraft emissions are immediately diluted into a grid cell air volume, larger-scale models will overestimate the calculated $\mathrm{O}_{3}$ production resulting from aircraft $\mathrm{NO}_{x}$ emissions by about $30 \%$.

Over a typical residence time of air in the upper troposphere, the plume scale model suggests that on average, each aircraft emitted $\mathrm{NO}_{\mathrm{x}}$ molecule induces the production of about 2-3 molecules of $\mathrm{O}_{3}$ per day as long as the reactive $\mathrm{NO}_{y}$ remains in the upper troposphere. During the first one or two days following emissions, instantly mixing aircraft $\mathrm{NO}_{\mathrm{x}}$ emissions over volumes of air typically used by global-scale atmospheric chemistry models leads to an overestimate of about 8 - 9 molecules of $\mathrm{O}_{3}$ produces per aircraft $\mathrm{NO}_{x}$ emitted. This overestimated increment of ozone formation remains constant for all times after the first few days.

In this study, a simple adjustment method was suggested to reduce the error in calculating $\mathrm{O}_{3}$ production in large-scale models of aircraft emissions. Since to a first order approximation the net $\mathrm{O}_{3}$ formation rate is regulated by the $\mathrm{NO}+\mathrm{HO}_{2}$ reaction, the $\mathrm{O}_{3}$ formation rate can be reduced by adjusting the reaction coefficient of the $\mathrm{NO}+\mathrm{HO}_{2}$ reaction. Applying this method avoids the complexity of dividing a model grid cell into several subgrids (Sillman et al. 1990a, 1990b) or more expensively increasing Eulerian model resolution to higher levels. This adjustment effectively reduces $\mathrm{O}_{3}$ formation rates in a chemically reasonable manner rather than simply removing $\mathrm{O}_{3}$ whenever aircraft $\mathrm{NO}_{x}$ emissions are occurring as suggested by Petry et 
al. (1998). By reducing this key reaction rate, calculated $\mathrm{O}_{3}$ formation rates are reduced and the $\mathrm{O}_{3}$ concentrations calculated by instantly diluting the $\mathrm{NO}_{x}$ emissions are empirically nudged to the more realistic $\mathrm{O}_{3}$ concentrations calculated using an explicit simulation of the chemistry of the plume and the ambient environment. In the typical upper tropospheric conditions considered in this study, less than 3\% adjustments for the reaction coefficient appreciably lowers calculated $\mathrm{O}_{3}$ production and results in more realistic calculated $\mathrm{O}_{3}$ perturbations.

The overestimated $\mathrm{O}_{3}$ production due to instant dilution of aircraft emissions into a larger scale air volume is a function of ambient conditions. Under larger vertical diffusion coefficients, wind shear, ambient $\mathrm{NO}_{x}$ and $\mathrm{O}_{3}$ concentrations, the overestimated $\mathrm{O}_{3}$ production is smaller. The optimum adjustment factor that reduces this error will also vary. Further studies are needed to find the appropriate adjustment factor under different ambient conditions encountered in the upper troposphere.

It is acknowledged that the actual distributions of aircraft plumes applied to regional or global scale models are complex and the calculated $\mathrm{O}_{3}$ perturbations due to aircraft emissions vary with location and time. Therefore, it is almost impossible to adjust the $\mathrm{O}_{3}$ production at each location and time. For practical applications of the method proposed here to global-scale modeling, one could adjust the rate coefficient in a specified sub-domain where aircraft $\mathrm{NO}_{x}$ plumes are known to be present, such as in the actual $\mathrm{NO}_{\mathrm{x}}$ emissions region or the zonal areas downwind of these emission regions. Once a spatial area of adjustment is defined, the mean shear conditions there can be used to calculate the reaction adjustment factor as suggested above.

\section{REFERENCES}

Aikin, A. C., C. C. Gallagher, C. W. Spicer, and M. W. Holdren, 1987: Measurement of methane and other light hydrocarbons in the troposphere and lower stratosphere. $J$. Geophys. Res., 92, 3135-3138.

Baughcum, S. L., 1996: Subsonic aircraft emissions inventories. In: A. M. Thompson, R. R. Friedl and H. L. Wesoky (Eds.), Atmospheric Effects of Aviation: First Report of the Subsonic Assessment Project, NASA Reference Publication 1385, 15-29.

Baughcum, S. L., 1997: Aircraft Emissions. In: R. R. Friedl (Eds.), Atmospheric Effects of Subsonic Aircraft: Interim Assessment Report of the Advanced Subsonic Technology Program, NASA Reference Publication 1400, 5-26.

Beck, J. P., C. E. Reeves, F. A. A. M. de Leeuw, and S. A. Penkett, 1990: The Effect of Aircraft Emissions on Atmospheric Ozone in the Northern Hemisphere. Report nr. 222201001, National Institute of Public Health and Environmental Protection, Bilthoven, the Netherlands and School of Environmental Sciences, University of East Anglia, Norwich, United Kingdom.

Brasseur, G. P., J. Muller, and C. Granier, 1996: Atmospheric impacts of $\mathrm{NO}_{x}$ emissions by subsonic aircraft: A three-dimensional model study. J. Geophys. Res., 101, 1423-1428.

Chatfield, R. B. and A. C. Delany, 1990: Convection links biomass burning to increased ropical ozone: However, models will tend to overpredict $\mathrm{O}_{3}$.J. Geophys. Res., 95, 18, 
473-18,488.

Costen, R. C., G. M. Tennille, and J. S. Levine, 1988: Cloud pumping in a one-dimensional photochemical model. J. Geophys. Res., 93, 15,941-15,954.

Danilin, M. Y., A. Ebel, H. Elbem, and H. Petry, 1994: Evolution of the concentrations of trace species in an aircraft plume: Trajectory study. J. Geophys. Res., 99, 18,951-18, 972.

Derwent, R. G., 1982: Two-dimensional model studies of the impact of aircraft exhaust emissions on tropospheric ozone. Atmos. Environ., 16, 1997-2007.

Dürbeck, T. and Gerz, T., 1995: Large-eddy simulation of aircraft exhaust plumes in the free atmosphere: effective diffusivities and cross-sections. Geophys. Res. Let., 22, 32033206.

Dürbeck, T. and Gerz, T., 1996: Dispersion of aircraft exhausts in the free atmosphere. $J$. Geophys. Res., 101, 26,007-26,015.

Hayman, G. D. and M. Markiewicz, 1996: Chemical Modelling of the Aircraft Exhaust Plume. In: U. Schumann (Eds.), Pollution from Aircraft Emissions in the North Atlantic Flight Corridor (POLINAT), Air pollution Research Report 58, European Commission, 280303.

Hidalgo, H. and P. J. Crutzen, 1977: The tropospheric and stratospheric composition perturbed by $\mathrm{NO}_{x}$ emissions of high-altitude aircraft. J. Geophys. Res., 82, 5833-5866.

Jang, J. C., H. E. Jeffries, D. Byun and J. E. Pleim, 1995: Sensitivity of ozone to model grid resolution-I. Application of high-resolution regional acid deposition model. Atmos. Environ., 29, 3085-3100.

Johnson, C. E. and D. S. Stevenson, 1996: Effect on tropospheric oxidant concentrations resulting from aircraft $\mathrm{NO}_{x}$ emissions. In: U. Schumann (Ed.), Pollution from Aircraft Emissions in the North Altantic Flight Corridor (POLINAT), Air Pollution Research Report 58, European Commission, 175-202.

Konopka, P., 1995: Analytical Gaussian solutions for anisotropic diffusion in a linear shear flow. J. Non-Equilib. Thermodyn., 20, 78-91.

Konopka, P., 1996: Spatial and temporal variability of $\mathrm{NO}_{\mathrm{x}}$ increase from aviation emissions in the North Atlantic flight corridor. In: U. Schumann (Ed.), Pollution from aircraft emissions in the North Atlantic flight corridor (POLINAT), Air Pollution Research Report 58, European Commission, 223-233.

Kraabøl, A. G., P. Konopka, F. Stordal, and S. Knudsen, 1996: Turbulent mixing and chemistry in the aircraft wake. In: U. Schumann (Ed.), Pollution from aircraft emissions in the North Altantic Flight Corridor (POLINAT), Air pollution research report 58, European Commission, 234-257.

Lacis, A. A., D. J. Wuebbles, and J. A. Logan, 1990: Radiative forcing of climate by changes in the vertical redistribution of ozone. J. Geophys. Res., 95, 9971-9981.

Lin, X., F. Zaucker E.-Y. Hsie, M. Trainer, and S. A. McKeen, 1996: Radon 222 simulations as a test of a three-dimensional regional transport model. J. Geophys. Res., 101, 29, $165-29,177$.

Liu, S. C., M. Trainer, F. C. Fehsenheld, D. D. Parrish, E. J. Williams, D. W. Fahey, G. Hubler, and P. C. Murphy, 1987: Ozone production in the rural troposphere and the 
implications for regional and global ozone distributions. J. Geophys. Res., 92, 4,191-4, 207.

Liu, S. C., S. A. McKeen, E-Y. Hsie, X. Lin, K. K. Kelly, J. D. Bradshaw, S. T. Sandholm, E. V. Browell, G. L. Gregory, G. W. Sachse, A. R. Bandy, D. C. Thomton, D. R. Blake, F. S. Rowland, R. Newell, B. G. Heikes, H. Singh, and R. W. Talbot, 1996: Model study of tropospheric trace species distributions during PEM-West A. J. Geophys. Res., 101, 2073-2085.

Meijer, E. W., P. F. J. van Velthoven, A. M. Thompson, L. Pfister, H. Schlager, P. Schulte, and $\mathrm{H}$. Kelder, 2000: Model calculations of the impacts of $\mathrm{NO}_{\mathrm{x}}$ from air raffic, lightning, and surface emissions, compared with measurements. J. Geophys. Res., 105, 38333850 .

Metwally, M., 1995: Jet Aircraft Engine Emissions Database Development - 1992 Military, Charter and Nonscheduled Traffic, NASA CR-4684.

Murphy, D. M., D. W. Fahey, M. H. Proffitt, S. C. Liu, K. R. Chan, C. S. Eubank, S. R. Kawa, and K. K. Kelly, 1993: Reactive nitrogen and its correlation with ozone in the lower stratosphere and upper troposphere. J. Geophys. Res., 98, 8751-8773.

Nastrom, G. D. and K. S. Gage, 1985: A climatology of atmospheric wave number spectra of wind and temperature observed by commercial aircraft. J. Atmos. Sci., 42, 950-960.

Nastrom, G. D., D. C. Fritts, and K. S. Gage, 1987: Investigation of terrain effects on the mesoscale spectrum of atmospheric motions. J. Atmos. Sci., 44, 3087-3096.

Pearson, H. J., J. S. Puttock, and J. C. R. Hunt, 1983: A statistical model of fluid-element motions and vertical diffusion in a homogeneous stratified turbulent flow. J. Fluid Mech., 129, 219-249.

Petry, H. J. Hendricks, M. Mollhoff, E. Lippert, A. Meier, and A. Ebel, 1998: Chemical conversion of subsonic aircraft emissions in the dispersing plume: Calculation of effective emission indices. J. Geophys. Res., 103, 5759-5772.

Pleim, J. E., J. S. Chang and K. Zhang, 1991: A nested grid mesoscale atmospheric chemistry model. J. Geophys. Res., 96, 3065-3084.

Ray, J. D., C. C. Van Valin, and J. F. Boatman, 1992: The vertical distribution of atmospheric $\mathrm{H}_{2} \mathrm{O}_{2}$ : A case study. J. Geophys. Res., 97, 2507-2517.

Schultz, M. G., D. J. Jacob, Y. Wang, J. A. Logan, E. L. Atlas, D. R. Blake, N. J. Blake, J. D. Bradshaw, E. V. Browell, M. A. Fenn, F. Flocke, G. L. Gregory, B. G. Heikes, G. W. Sachse, S. T. Sandholm, R. E. Shetter, H. B. Singh, and R. W. Talbot, 1999: On the origin of tropospheric ozone and $\mathrm{NO}_{\mathrm{x}}$ over the tropical South Pacific. J. Geophy. Res., 104, 5829-5843.

Schumann, U., P. Konopka, R. Baumann, R. Busen, T. Gerz, H. Schlager, P. Schulte, and H. Volkert, 1995: Estimate of Diffusion Parameters of Aircraft Exhaust Plumes Near the Tropopause from Nitric Oxide and Turbulence Measurements. J. Geophy. Res., 100, 14,147-14,162.

Schumann, U., 1997: The impact of nitrogen oxides emissions from aircraft upon the atmosphere at flight altitudes - Results from the Aeronox project. Atmos. Environ., 31, 17231733.

Sillman, S., J. A. Logan, and S. C. Wofsy, 1990a : The sensitivity of ozone to nitrogen oxides 
and hydrocarbons in regional ozone episodes. J. Geophy. Res., 95, 1837-1851.

Sillman, S., J. A. Logan, and S. C. Wofsy, 1990b: A regional scale model for ozone in the United States with subgrid representation of urban and power plant plumes. J. Geophy. Res., 95, 1837-1851.

Stockwell, W. R., P. Middleton, and J. S. Chang, 1990: The Second Generation Regional Acid Deposition Model Chemical Mechanism for Regional Air Quality Modeling. $J$. Geophys. Res., 95, 16,343-16,367.

Thompson, A. M., 1984: The effect of cloud on photolysis rates and $\mathrm{O}_{3}$ formation in the unpolluted troposphere. J. Geophys. Res., 89, 1341-1349.

Tsai, F.-J., 1999: Plume-scale and Regional-scale Modeling Studies of Uncertainties Associated with Calculated Impacts of Aircraft Emissions on Upper Tropospheric $\mathrm{O}_{3}, \mathrm{Ph} . \mathrm{D}$. Thesis, State University of New York at Albany, Albany, New York, USA.

Wang, W.-C., J. P. Pinto, and Y. L. Yung, 1980: Climatic effects due to halogenated compounds in the earth's atmosphere. J. Atmos. Sci., 37, 333-338.

Weinheimer, A. J., J. G. Walega, B. A. Ridley, B. L. Gary, D. R. Blake, N. J. Blake, F. S. Rowland, G. W. Sachse, B. E. Anderson, and J. E. Collins, 1994: Meridional distributions of $\mathrm{NO}_{\mathrm{x}}, \mathrm{NO}_{\mathrm{y}}$ and other species in the lower stratosphere and upper troposphere during AASE II. Geophy. Res. Lett., 21, 2583-2586. 